\title{
2936. Literature review of tire-pavement interaction noise and reduction approaches
}

\author{
Tan Li \\ Department of Mechanical Engineering, Virginia Tech, Blacksburg, VA, 24061, USA \\ Maxxis Technology Center, Suwanee, GA, 30024, USA \\ E-mail:L@vt.edu,tli@maxxis.com \\ Received 29 March 2018; accepted 9 May 2018 \\ DOI https://doi.org/10.21595/jve.2018.19935
}

Check for updates

Copyright (C) 2018 Tan Li. This is an open access article distributed under the Creative Commons Attribution License, which permits unrestricted use, distribution, and reproduction in any medium, provided the original work is properly cited.

\begin{abstract}
Tire-pavement interaction noise (TPIN) dominates for passenger vehicles with the speed of above $40 \mathrm{~km} / \mathrm{h}$ and for trucks with the speed of $70 \mathrm{~km} / \mathrm{h}$. With the prevailing trend of electric vehicles, TPIN can become more NVH (Noise, Vibration, and Harshness) issue in the future. In this paper, the vehicle noise and tire noise were briefly reviewed in the background introduction. Then the motivation of and approaches to reducing tire noise was reviewed from open literature. It was found that the tire industry and the pavement industry have been working individually on designing and building quiet tire and quiet pavement for many decades. However, the interaction between tire and pavement was less investigated. The future research on reducing TPIN can be the combined consideration of both tire and pavement characteristics while maintaining other performances, such as traction, handling, rolling resistance, hydroplaning, and durability.
\end{abstract}

Keywords: tire noise, noise reduction, quiet tire, quiet pavement.

\section{Introduction}

Tire-pavement interaction noise (TPIN) is defined as the noise emitted from a rolling tire as a result of the interaction between the tire and road surface (Sandberg and Ejsmont, 2002 [1]), which is also known as tire-road interaction noise, tire/pavement noise, tire/road noise (TRN), or tire noise. TPIN has been extensively investigated since 1970's (Li et al., 2018 [2]). In this paper, the relationship between TPIN and vehicle noise is first introduced. Then, the categorization of TPIN is discussed. Next, the motivation of reducing TPIN is explained. Last, the TPIN reduction approaches are reviewed.

\section{Vehicle noise}

Noise, vibration, and harshness $(\mathrm{NVH})$, a.k.a., noise and vibration $(\mathrm{N} \& \mathrm{~V})$ represents a quality factor in the automotive engineering (Mohamed, 2013 [3]). It is generally accepted that there are five major sources of noise for a running vehicle: engine (power train), intake system, exhaust system, aerodynamic turbulence (wind) and tire-pavement interaction (Braun et al., 2013 [4]), as shown in Fig. 1 (Bosch, 2004 [5]). The power train noise is generated primarily due to combustion in the engine, gas flow, and mechanical movement of the transmission parts. The aerodynamic noise depends on vehicle geometry and speed of the vehicle, generated due to aerodynamic friction and turbulence caused by the vehicles moving at higher speeds. The combination of engine (power train), intake system, exhaust system is also called as the propulsion system which the performance is largely dependent on the engine speed; they have coherent noise sources and are interacting with each other, but they are incoherent with tire noise (Fry et al., 1999 [6]). It is reasonable to infer that for the same vehicle speed, lower gear generates more noise since the engine speed is higher, as shown in Fig. 2 (Biermann, 2004 [7]). It can be seen that the noise level is relatively independent of torque except when rpm is below 1000. The intake orifice noise versus engine speed is displayed in Fig. 3 (Zeller, 2009 [8]). The exhaust noise versus engine speed is displayed in Fig. 4, and its typical spectrum is shown in Fig. 5 (Alfredson and Davies, 1970 [9]). For vehicle 
noise from trucks, the supplementary braking noise (pneumatic cylinders) and "body slap" are often important (NZ Transport Agency, 2014 [10]).

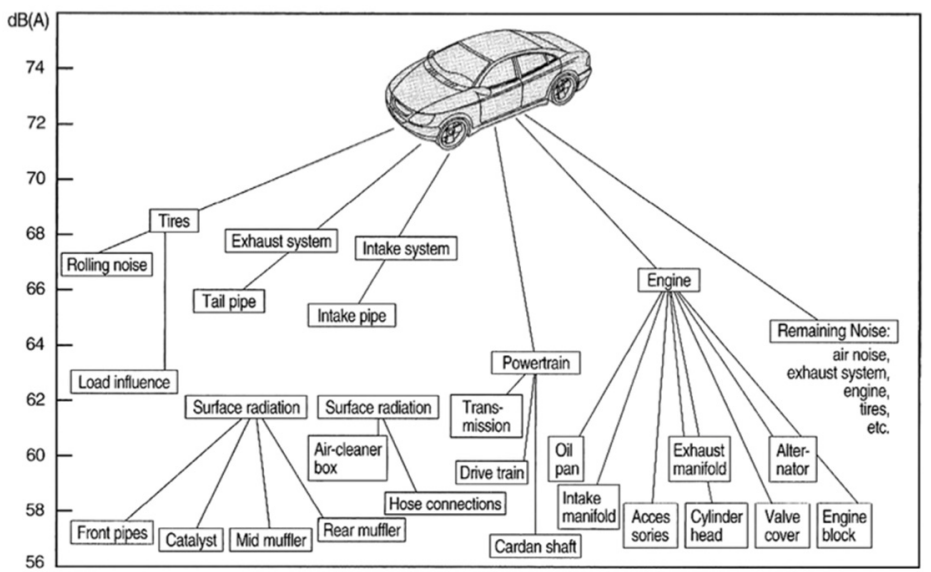

Fig. 1. Noise source ranking for a vehicle during the pass-by noise test (source from Braun et al., 2013 [4], Fig. 21; original from Bosch, 2004 [5]; reprinted with permission from Elsevier)

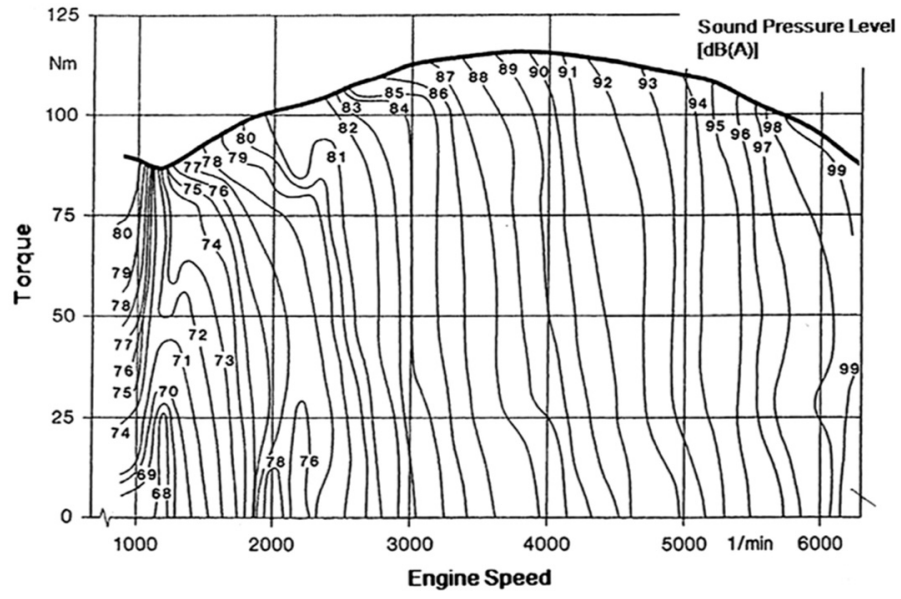

Fig. 2. Engine noise map of sound pressure level versus torque and rotational speed (source from Braun et al., 2013 [4], Fig. 11; original from Biermann, 2004 [7]; reprinted with permission from Elsevier)

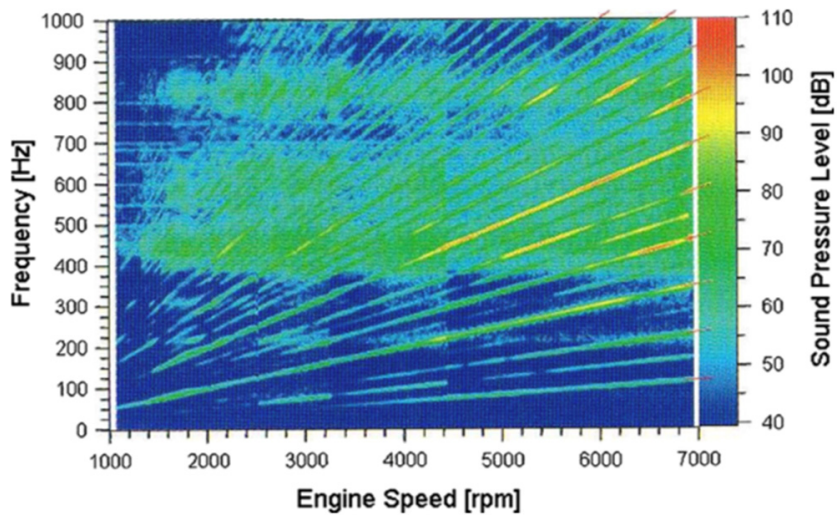

Fig. 3. Sound pressure level of intake orifice noise versus engine speed and frequency (source from Braun et al., 2013 [4], Fig. 14; original from Zeller, 2009 [8]; reprinted with permission from Elsevier) 


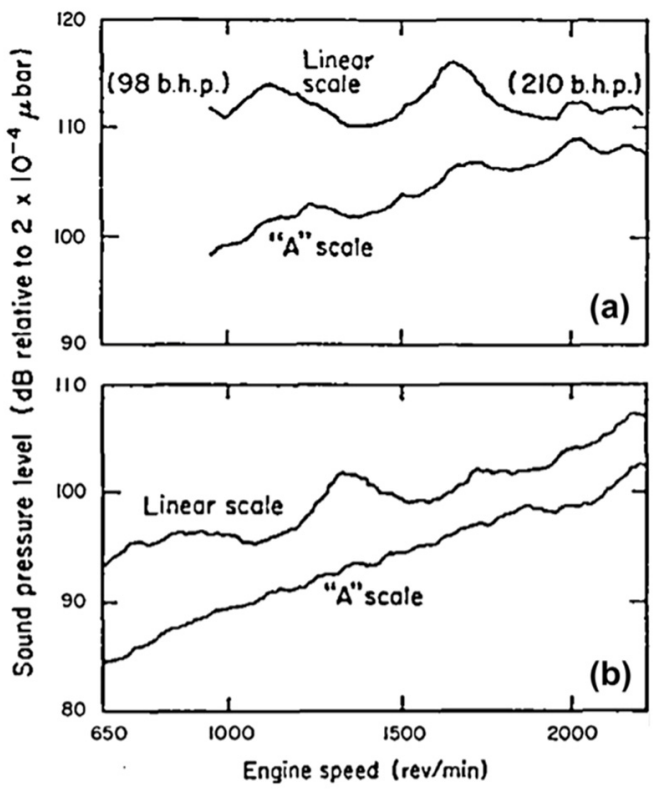

Fig. 4. Sound pressure level of exhaust noise versus engine speed (source from Braun et al., 2013 [4], Fig. 16; original from Alfredson and Davies, 1970 [9]; reprinted with permission from Elsevier)

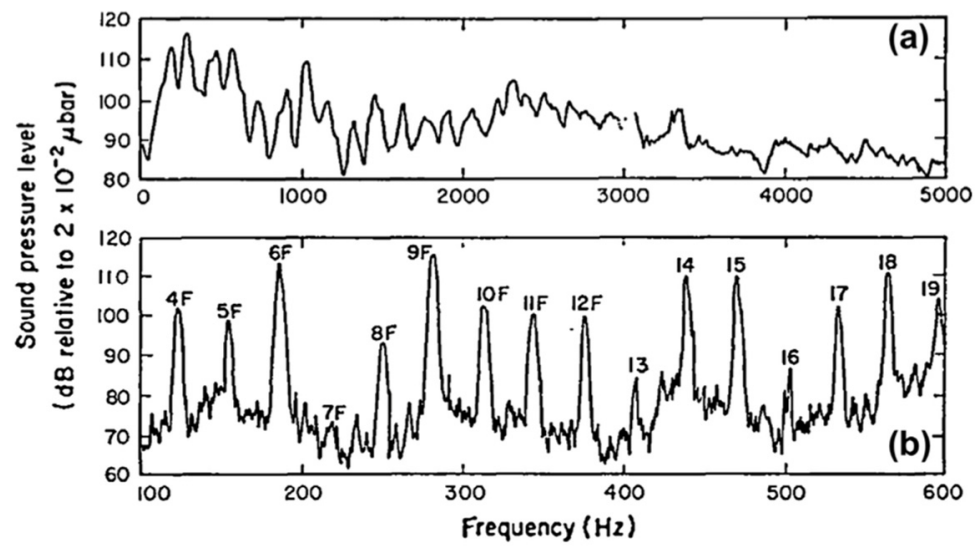

Fig. 5. Typical frequency spectrum of exhaust noise measured at $1880 \mathrm{rpm}$ and $0.9 \mathrm{~m}$ from the outlet: a) 0-5000 Hz; (b) 100-600 Hz (source from Braun et al., 2013 [4], Fig. 17; original from Alfredson and Davies, 1970 [9]; reprinted with permission from Elsevier)

These noise sources contribute differently for a different speed, as illustrated in Fig. 6, including propulsion noise, tire-pavement interaction noise and aerodynamic noise. Sandberg (2001) [11] indicated that the tire-pavement interaction noise dominates for passenger vehicles with the speed of above $40 \mathrm{~km} / \mathrm{h}$ and for trucks with the speed of $70 \mathrm{~km} / \mathrm{h}$. Engine noise is dominant at a low speed in low frequencies (Yang et al., 2011 [12]) shown in Fig. 7 (Bravo et al., 2012 [13]), while aerodynamic noise is important only at a very high speed $(15 \%$ at $150 \mathrm{~km} / \mathrm{h}$ [14]) and only at low frequencies $(50-400 \mathrm{~Hz}$ [15]). The intake and exhaust noise also centers around low frequencies, as shown in Fig. 8 (Freeman and Cerrato, 2011 [16]). It was reported that air turbulence noise was still more than $10 \mathrm{~dB}$ lower than TPIN even at a speed of $90 \mathrm{~km} / \mathrm{h}$ for frequencies between $315 \mathrm{~Hz}$ and $5 \mathrm{kHz}$, and engine and exhaust noise were negligible (Dubois et al., 2013 [17]). 


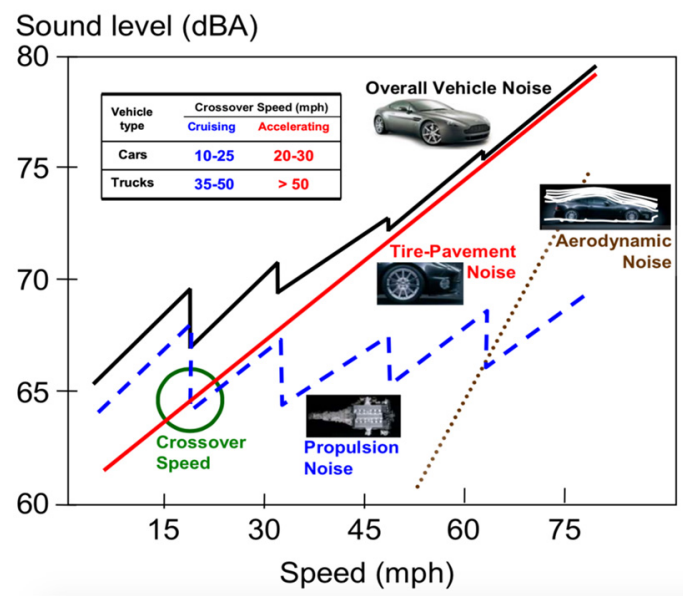

Fig. 6. Vehicle noise components versus speed (source from Rasmussen et al., 2007 [18], Fig. 7; reprinted with permission from Dr. Robert Otto Rasmussen of The Transtec Group, Inc., USA)

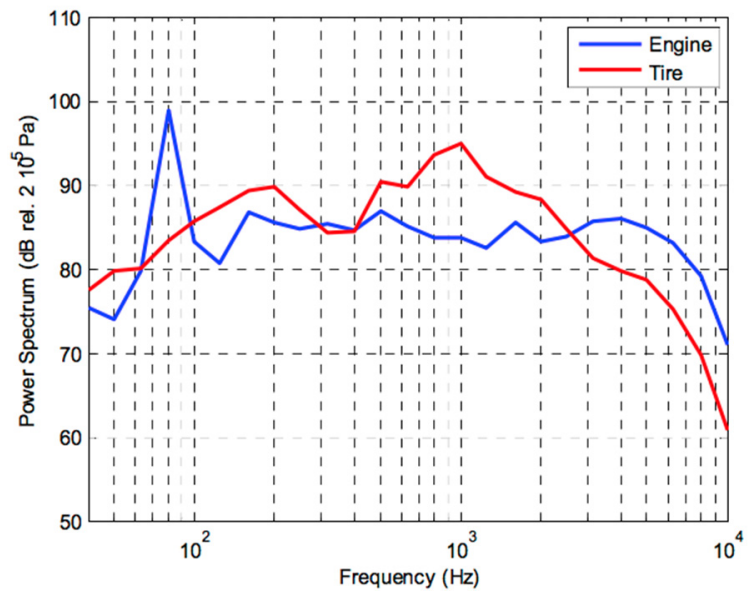

Fig. 7. Power spectrum of the microphone signals situated close to the engine (blue) and close to the tire (red) for pass-by velocity of $70 \mathrm{~km} / \mathrm{h}$ (source from Bravo et al., 2012 [13],

Fig. 3; reprinted with permission from ASME)

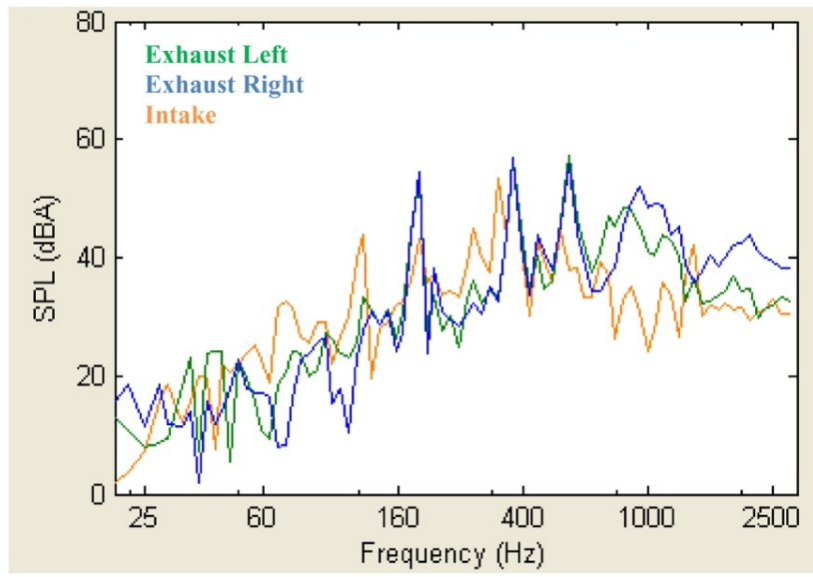

Fig. 8. Noise emissions from exhaust and intake system (source from Freeman and Cerrato, 2011 [16], Fig. 4; reprinted under fair use provision) 
That is to say, at a normal highway speed, tire-pavement interaction noise is the most important noise contributor [19] (up to $80-90 \%$ at a speed of over $70-80 \mathrm{~km} / \mathrm{h} \mathrm{[20]).} \mathrm{It} \mathrm{seems} \mathrm{not} \mathrm{to} \mathrm{be} \mathrm{the}$ common established thought, that is, engine is the dominant noise source. It was true before 1970's, however, as engine and exhaust became less noisy, and the aerodynamic design of vehicle body was optimized (Dechipre et al., 2010 [21]), the tire-pavement interaction noise became more and more dominant, as shown in Fig. 9 (Sandberg, 2001 [22]). The trend of electric motor replacing combustion engine also plays a great role in this change now and in the future (Gasparoni et al., 2014 [23]). Sandberg (2001) [11] further claimed that usually tire noise dominates during almost all types of driving for cars and down to about $40 \mathrm{~km} / \mathrm{h}$ for trucks (vehicles meeting EU requirements), as shown in Fig. 10 (Bernhard and Wayson, 2005 [24]).

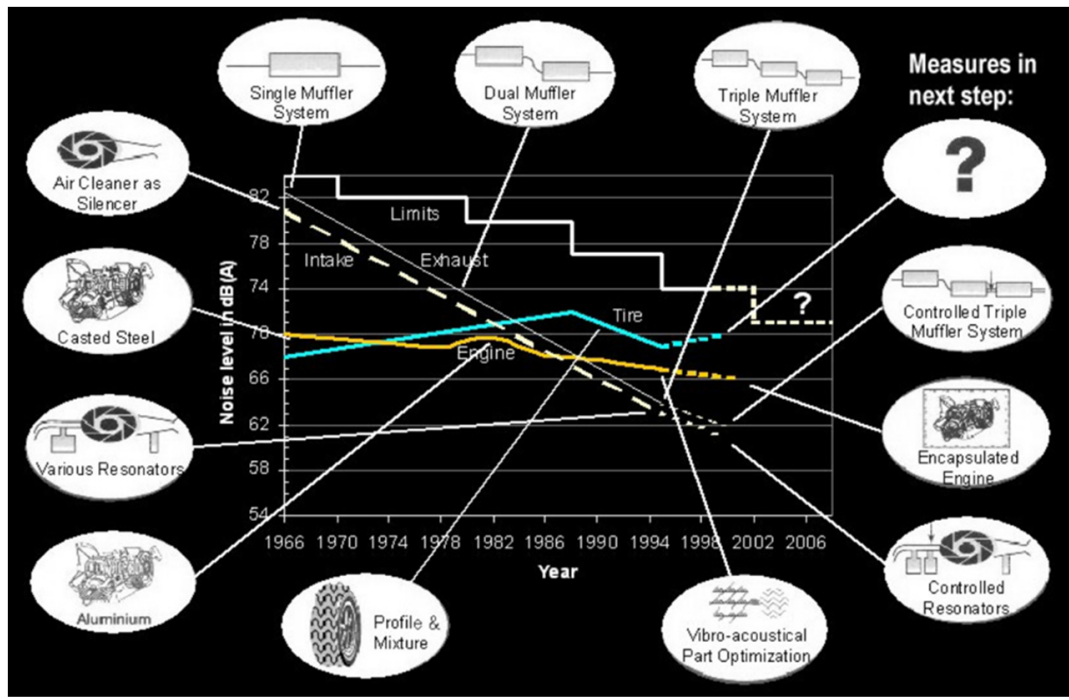

Fig. 9. The most important reduction measures employed in a common car in order to satisfy various steps in tightened noise emission limits in Germany and the EU. Note that the curves indicate how the limits and the sources engine, intake, exhaust and tire have developed over time. (Source from Sandberg, 2001 [22], Fig. 3; reprinted under fair use provision)

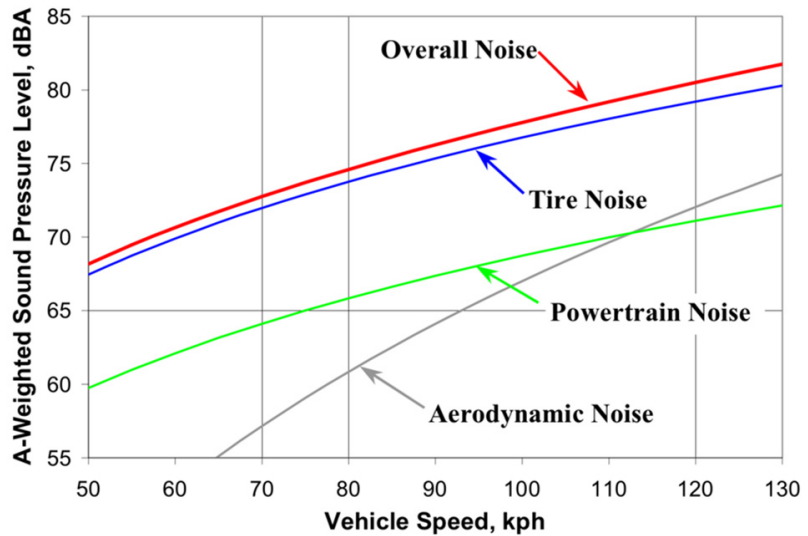

Fig. 10. Contributions of various sub-sources of highway traffic noise (source from Bernhard and Wayson, 2005 [24], Fig. 11; reprinted with permission from Ms. Amy Miller of Asphalt Pavement Alliance)

Schuhmacher (2015) [25] applied the blind source separation (BSS) technique to the indoor vehicle pass-by noise to separate the contributions from different components of the vehicle using 17 microphones. The results are below in Fig. 11. 


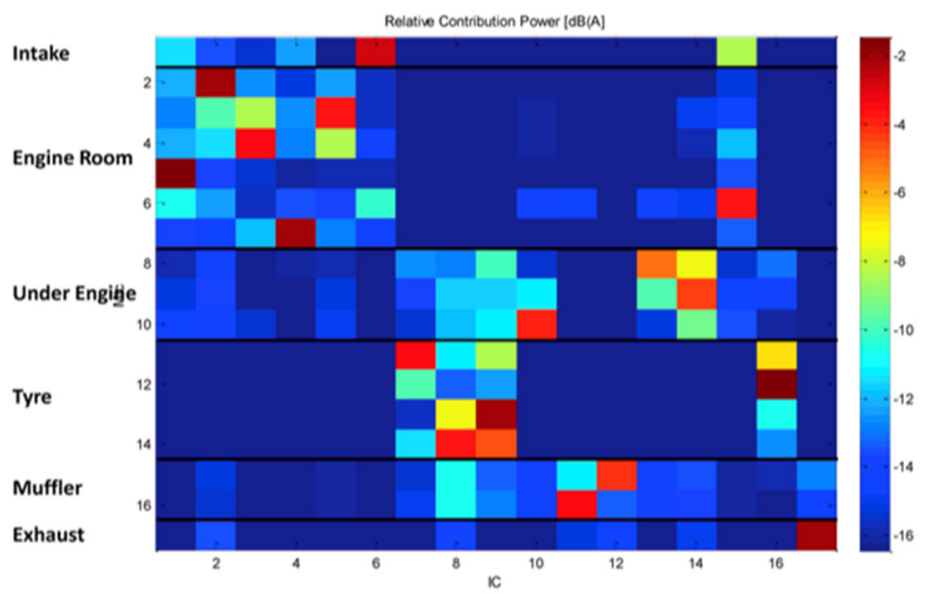

Fig. 11. Contribution matrix indicating the relative power contribution from each independent component (column) to each reference microphone (row) (source from Schuhmacher, 2015 [25], Fig. 11; reprinted under fair use provision)

\section{Noise categorization}

The three basic elements of noise are source, transmission path and receiver. Based on the noise generation mechanism (source) and the conveying medium (path), tire noise can be classified as structure-borne noise and airborne noise. Based on the position of the receiver, tire noise can be categorized as interior noise (inside the vehicle) and exterior noise (outside the vehicle). As such, there are basically four types of noise combining two sets of categories, as illustrated in Fig. 12 (He et al., 2011 [26]). When it comes to tire-pavement interaction noise, it usually refers to exterior noise, including both structure-borne and airborne.

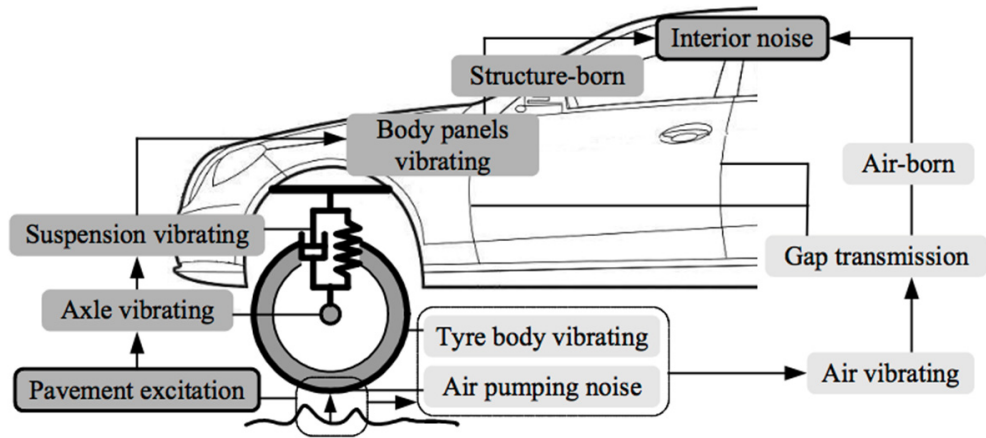

Fig. 12. Vehicle interior noise transmission path (source from He et al., 2011 [26], Fig. 2; reprinted with permission from Trans Tech Publications Ltd)

Structure-borne noise is generated from a vibration source, such as tread impact. The acoustic energy created by these vibrations is transmitted into and through a solid structure, such as rim, axle, suspension and vehicle body. Air-borne noise is generated directly due to air displacement such as air pumping. It should be noted that the acoustic energy of the structure-borne noise is finally released as airborne noise at the interface between the structure and air, and thus it can be heard. Airborne noise may also change into the structure-borne one, and usually back to airborne again, such as air pumping noise transmitted into interior noise through vibrations of windows. Structure-borne noise can be attenuated by vibration isolators, while airborne noise is reduced by absorption materials or through the use of sound barrier. Generally, in acoustics the difference between structure-borne and airborne noise is in the medium of transmission, but in terms of tire 
noise, the difference is sometimes focused on the noise generation mechanism, which is kind of misused. Strictly speaking, the latter should be called as the vibro-dynamic noise and aerodynamic noise, or vibro-acoustic noise and aeroacoustic noise.

The interior noise of vehicle is a completely different topic than the exterior noise (mainly TPIN). The spectral content of interior noise is focused around low frequencies, as shown in Fig. 13 (Chang et al., 2010 [27]). Jen and Lu (2007) [28] reported that the major road excitation input was below $50 \mathrm{~Hz}$, and the interior noise resonances caused by modes of tires and suspensions were mainly below $100 \mathrm{~Hz}$.

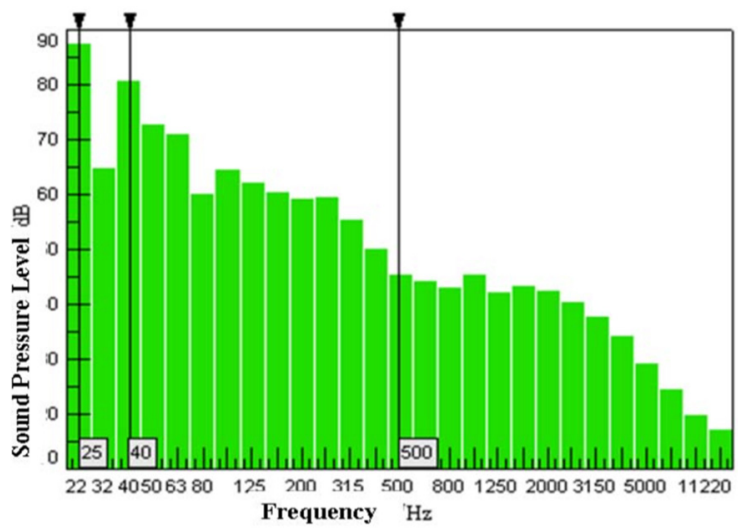

Fig. 13. Interior noise spectrum at speed $80 \mathrm{~km} / \mathrm{h}$ (source from Chang et al., 2010 [27],

Fig. 4; reprinted with permission from IEEE)

The three primary interior noise sources are engine, tire, and wind (Lim et al., 2014 [29]). The secondary sources can be mechanical devices such as ventilation fans (Aissaoui, 2015 [30]) and power windows (Johnsson and Nykänen, 2013 [31]). Chang et al. (2010) [27] indicated that tire becomes the dominant noise source for interior noise when the speed is over $80 \mathrm{~km} / \mathrm{h}$, and the structure-borne noise occurs mainly at low frequencies (below $500 \mathrm{~Hz}$ ) while the airborne one occurs at high frequencies (500-2000 Hz) (Lopez et al., 2007 [32]). Kitahara et al. (2011) [33] reported the same results, as shown in Fig. 14. Since the interior noise is mainly structure-borne noise, the transfer path analysis (Tsuji et al., 2015 [34]; Zhao, 2008 [35]) and multiple coherence filtering (MCF) are often utilized (Chang et al., 2010 [27]). Saguchi et al. (2007) [36] investigated the noise and vibration transmissibility for the forces and moments at the spindle, as shown in Fig. 15 [36]. Vertical force $F_{z}$ affects up to $500 \mathrm{~Hz}$, overturning moment $M_{x}$ and aligning moment $M_{y}$ have influence at around $200 \mathrm{~Hz}$, and lateral force $F_{y}$ is effective for $600 \mathrm{~Hz}$. Kido and Ueyama (2005) [37] speculated that it is due to suspension (Geluk et al., 2011 [38]) and wheel resonance. The comparison between the spectra of exterior noise and interior noise is displayed in Fig. 16.

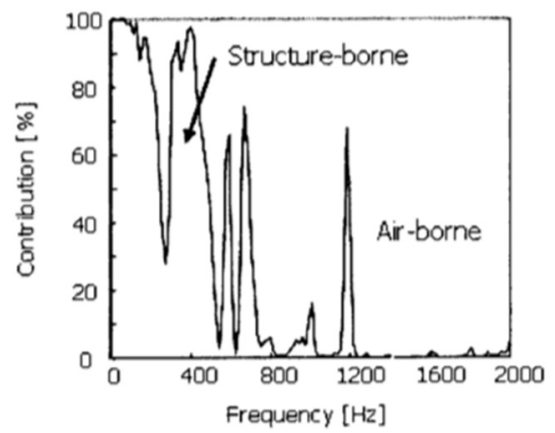

Fig. 14. Contribution of tire structure-borne and airborne noise for interior noise (source from Kitahara, 2011 [33], Fig. 2; reprinted under fair use provision) 


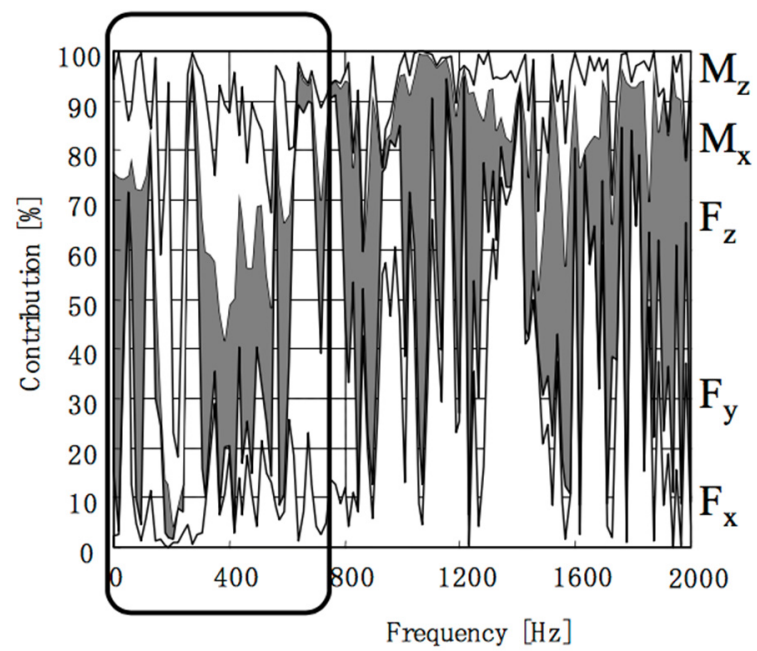

Fig. 15. Structure-borne interior noise due to spindle force and moment variations (source from Saguchi et al., 2007 [36], Fig. 13; reprinted under fair use provision)

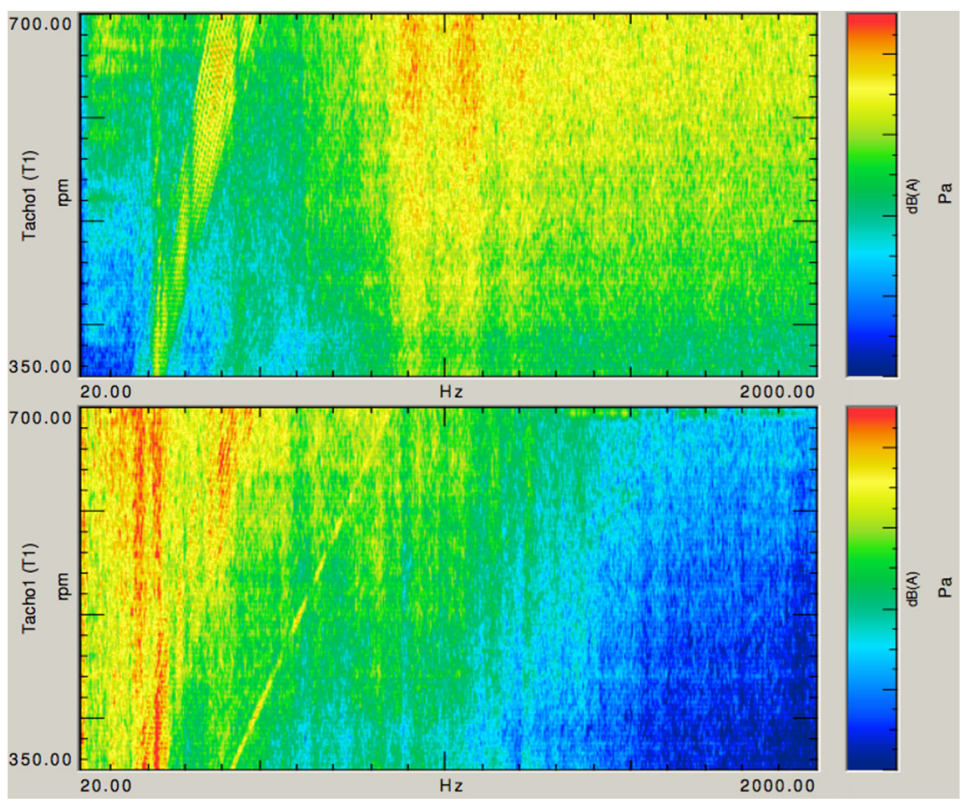

Fig. 16. Coast down measurement of exterior noise at the leading CPX (above) and interior noise at right-ear passenger seat (below) measured simultaneously (source from Bekke et al., 2010 [39], Fig. 5; reprinted under fair use provision)

Sotteck and Philippen (2010) [40] investigated the separation of airborne and structure-borne tire road interior noise using the Operational Path Analysis (OPA). The same authors (2012) [41] presented an approach combining the Operational Transfer Path Analysis (OTPA) and Cross-Talk Cancellation (CTC) to study the interior noise from tire under dynamic driving conditions, such as acceleration and deceleration when the engine noise is of more importance.

Pietrzyk (2001) [42] reported that the structural-borne noise from tire resonances below $400 \mathrm{~Hz}$ was believed to be transmitted through spindle and solid parts of the vehicle, and thus the interior noise came from the excited panels and surfaces of the cabin. Molisani et al. (2003) [43] identified that one such tire resonance is due to the tire acoustic cavity (resonance of the air column inside the tire cavity). 
He et al. (2011) [26] found that interior noise is greatly influenced by tire tread impact for some tires. As such, the dominant frequencies have a strong relation with the vehicle speed, which is not the case for the exterior noise. It is best shown in electric vehicles, since the rpm of electric motor is also proportional to speed, as shown in Fig. 17 (Fischer et al. 2014 [44]).

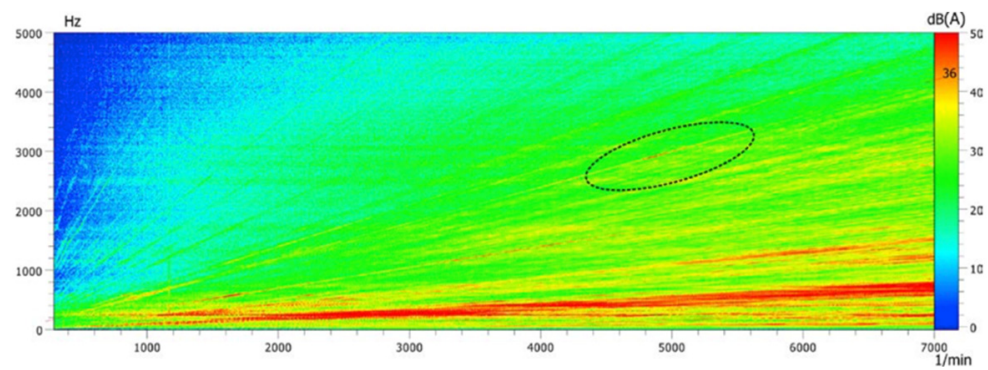

Fig. 17. Interior noise spectrum versus electric motor rpm $(80 \%$ accelerator pedal position measured on roller test bench) (source from Fischer et al. 2014 [44], Fig. 6; reprinted with permission from Mr. David Landes of Karlsruhe Institute of Technology, Germany)

The structural-acoustic finite element method is often used for modeling vehicle interior noise (Sung and Nefske, 2010 [45]), but it is only valid at low frequencies. Sung and Nefske (2009) [46] then presented a new statistical regression-based energy method for early vehicle design, which is suitable for high frequencies where the Statistical Energy Analysis (SEA) is often utilized in acoustics (Gur et al., 2015 [47]). Langhe et al. (2011) [48] proposed a hybrid modeling process where the Finite Element Method (FEM) with Auto Extruding Perfectly Matched Layer (AML) technologies is used for the low to mid frequency range while the Fast Multipole Boundary Element Method (FMBEM) for a higher frequency range, maintaining both the modeling accuracy and computation speed requirements.

For the interior noise, the sound balance or sound quality (shown in Fig. 18 [49]) is more of a concern than just making the vehicle quieter [29]. Due to the complexity of human hearing perception, two different noises with the same A-weighted level are not necessarily equally disturbing, then it can be partly explained by the psychoacoustics, including loudness, loudness level, sharpness, fluctuation strength, roughness and so on (Peng et al., 2010 [50]). The reduction of tones or addition of harmonics sometimes makes the interior noise more pleasant without changing the overall sound levels. The noise frequency range that mostly affects interior comfort is 50 to $200 \mathrm{~Hz}$ (Labor and Priebsch, 2007 [51]).

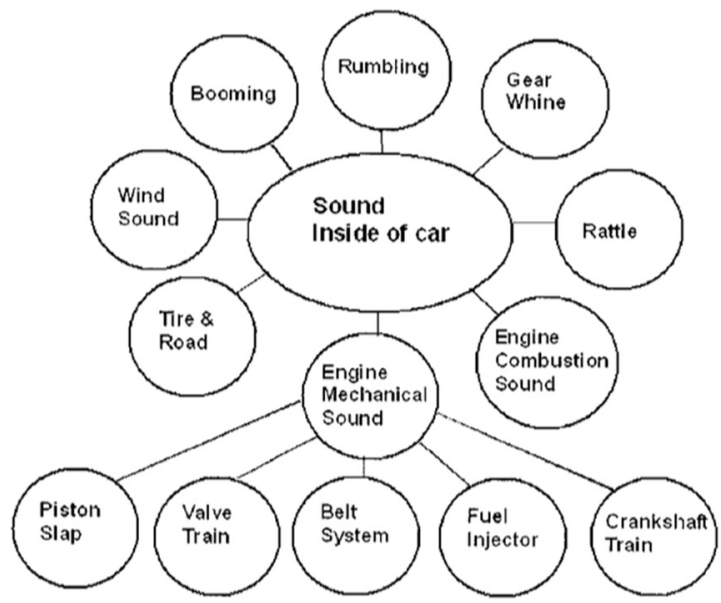

Fig. 18. Sound qualities in compartment of passenger car (source from Lee et al., 2005 [49], Fig. 1; reprinted with permission from Mr. Craig Myles on behalf of SAGE Ltd. Permissions Team) 


\section{Motivation of TPIN reduction}

The motivation for controlling tire-pavement interaction noise is multiple and different across different countries. One is to pass the legal approval for the exterior noise level; one is to reduce the annoyance level in the car interior space and increase passenger comfort (Harrison, 2004 [52]); one is to boycott foreign tire imports (Chen, 2014 [53]).

\subsection{Pollution}

"Environmental pollution" can be suggested by many people as air pollution, water pollution, or similar concepts. But another pollution, which is not quite visible but encountered by more and more cities, is noise pollution. Noise barriers that are up to 20 feet high have to be built to shield the neighborhoods from road noise for hundreds of yards along busy highways (Wayson, 2014 [54]). According to many opinion polls, the traffic noise is considered to be the number one noise nuisance affecting millions of people. Among the different sources of traffic noise (road vehicles, railways and airplanes), the sound generated by cars is most important because there are millions of them and because they are almost ubiquitous (Heckl, 1986 [55]).

European Commission Green Paper (1996) [56] pointed out that 110 million people (22\% of the EU population) are affected by sound pressure level greater than $65 \mathrm{dBA}$, and more than 225 million (45\% of the EU population) are exposed to noise levels above $55 \mathrm{dBA}$. It also indicated that road traffic noise is the most dominant source (over $90 \%$ ) of environmental noise in Europe, followed by rail traffic noise (Remington et al., 1983 [57]), aircraft noise and industrial noise. As such, traffic noise pollution becomes more and more concerned, as illustrated in Fig. 19 (Murphy and King, 2011 [58]).

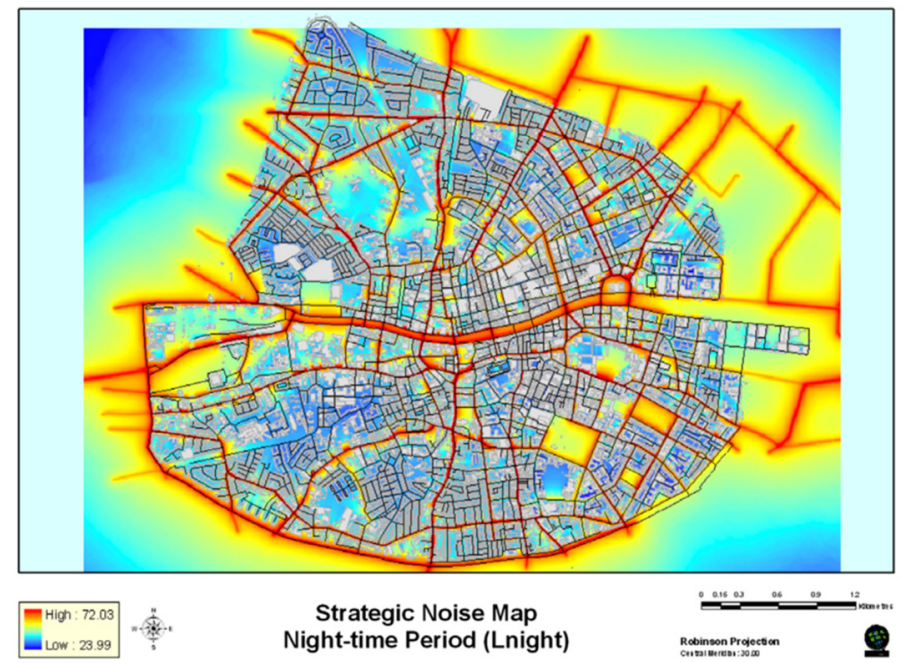

Fig. 19. Strategic noise map for the night-time period $\left(L_{\text {night }}\right)$ in Dublin, Ireland (source from Murphy and King, 2011 [58], Fig. 2; reprinted with permission from Elsevier)

According to the World Health Organization (WHO), noise is the second largest environmental cause of health issues, just after air quality (particulate matter). Sleepers exposed to night noise levels above long-term average $40 \mathrm{~dB}$ can suffer health effects like annoyance, sleep disturbance and awakenings. Above $55 \mathrm{~dB}$, cardiovascular disease, cognitive impairment and tinnitus can be triggered. It was estimated that each year noise pollution leaded to about 910 thousand additional prevalent cases of hypertension, 43 thousand hospital admissions, and at least 10 thousand premature deaths related to coronary heart disease and stroke (Kim, 2007 [59]). It was also indicated that 1-1.6 million healthy life years were lost every year from traffic noise in 
the EU cities.

In addition, truck drivers for long distance travelling exposed to continuous vehicle noise of high levels are easier to have health issues (Pan and Boulet, 2014 [60]). Loud traffic noise also affects animal behavior (Goodwin and Shriver, 2011 [61]; Lengagne, 2008 [62]; Bee and Swanson, 2007 [63]).

\subsection{Policy}

As traffic noise becomes more of a concern, the global regulations tend to have more and more tightening limits on the noise levels. After the INTER-NOISE 1992 conference in Toronto, the International Institute of Noise Control Engineering (I-INCE) started a global study on the effect of vehicle noise regulations on road traffic noise. The work was conducted by the Working Party on Noise Emissions of Road Vehicles (WP-NERV) including 13 members from 10 countries, of which Ulf Sandberg from the Swedish National Road and Transport Research Institute (VTI) was the convener. The final report (2001) [22] presented the changes of vehicle noise emission limits over 30 years (1970-2001), as shown in Fig. 20. Recommendations for future noise emission regulations were also given in the report since some regulations had a limited effect (Sandberg, $2001[22])$.

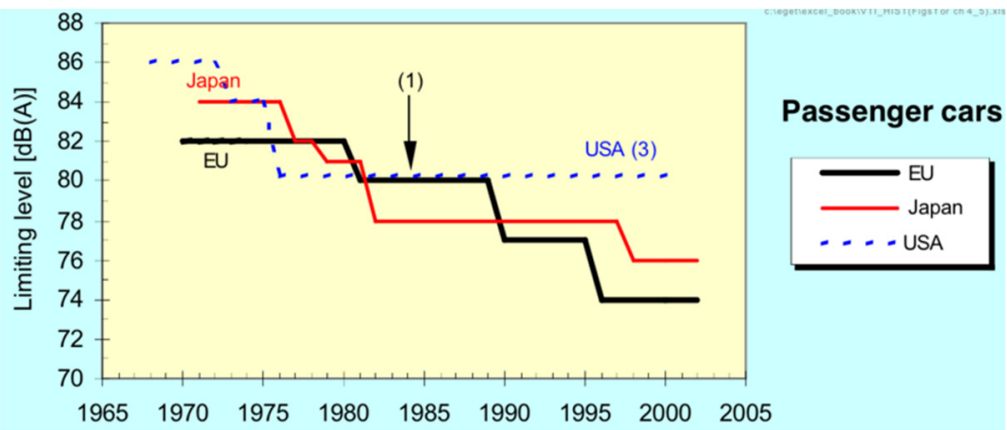

Fig. 20. Regulation limits for noise emission of passenger cars in European Union (EU), Japan and USA (source from Sandberg, 2001 [22], Fig. 1; reprinted under fair use provision)

In Fig. 20, it can be seen that Europe has the most stringent regulations on tire noise. The first relevant policy is Directive 70/157/EEC in 1970 (European Economic Community, 1970 [64]). The main current regulation on environmental noise is Directive 2002/49/EC (2002) [65]. For road traffic noise, the current regulations are Regulation (EU) 540/2014 (2014) [66] for motor vehicles and Regulation (EU) 168/2013 (2013) [67] for motor cycles. For tire noise, Directive 2001/43/EC (2001) [68] indicates the noise emission limits for new tires, as shown in Fig. 21 (FEHRL, 2001 [69]). In 2009, Regulation (EC) 661/2009 [70] and Regulation (EC) 1222/2009 [71] require revised noise limits (more stringent) for tire approval, as shown in Fig. 22, and mandatory tire labeling beginning from November 2012 as shown in Fig. 23. The tire approval process is in UN/ECE R117/2011 (2011) [72] and UN/ECE R51/2011 (2011) [73] requiring the measurement of rolling resistance, wet grip and pass-by noise. In the future, for M1a vehicles $(99 \%$ of the current car population) it is planned to limit the noise to $72 \mathrm{dBA}$ in 2016 then to $68 \mathrm{dBA}$ in 2024 , affecting roughly $85 \%$ of the current car population (ACEA, 2012 [74]). The Dutch National Traffic and Transportation indicated the goal regarding noise nuisance caused by road traffic: decreasing the number of houses exposed to a noise level of $>70 \mathrm{dBA}$ by $100 \%$, the number $>65 \mathrm{dBA}$ by $90 \%$ and the number $>60 \mathrm{dBA}$ by $50 \%$ in 2030 (Nijland et al., 2003 [75]). China also introduces tire labeling system for voluntary tire certification including tire noise, as shown in Fig. 24 (RenMinWang, 2016 [76]). 


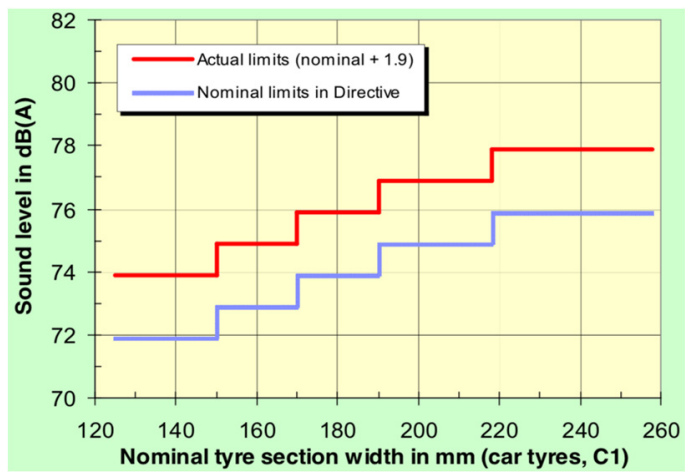

Fig. 21. Noise emission limits according to Directive 2001/43/EC (source from FEHRL, 2001 [69],

Appendices Fig. 3; reprinted under fair use provision)

\section{Sound Pressure Level vs Tyre Section Width (ISO 10844)}

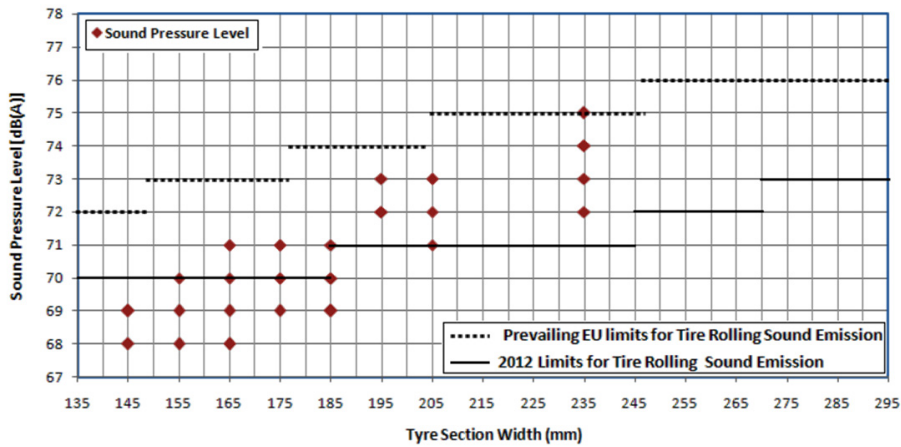

Fig. 22. Noise emission limits according to Regulation (EC) 661/2009 (modified from EC, 2009 [70]; reprinted under fair use provision)

\section{Tyre Labelling Information}

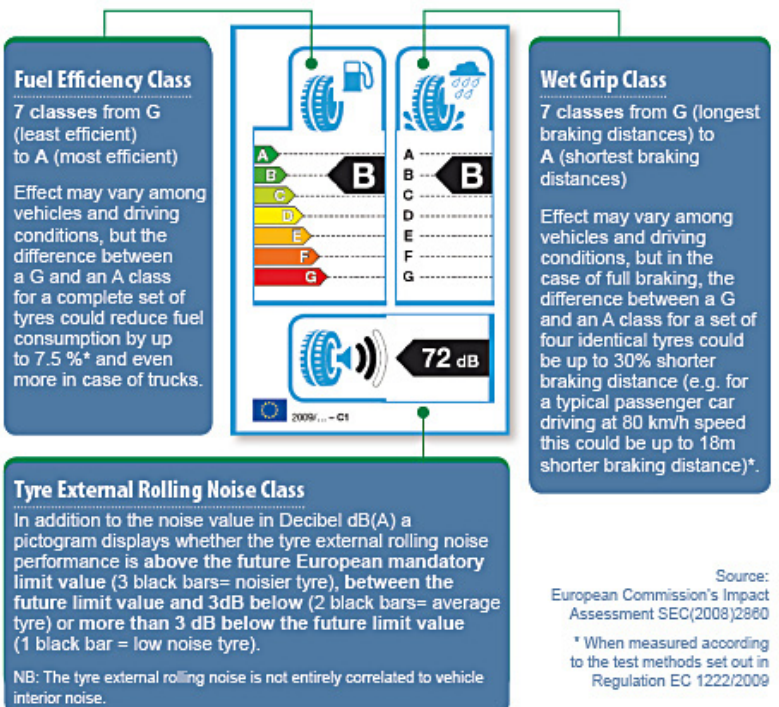

Fig. 23. Tire labeling information (source from ETRMA, 2011 [77]; reprinted with permission from ETRMA) 


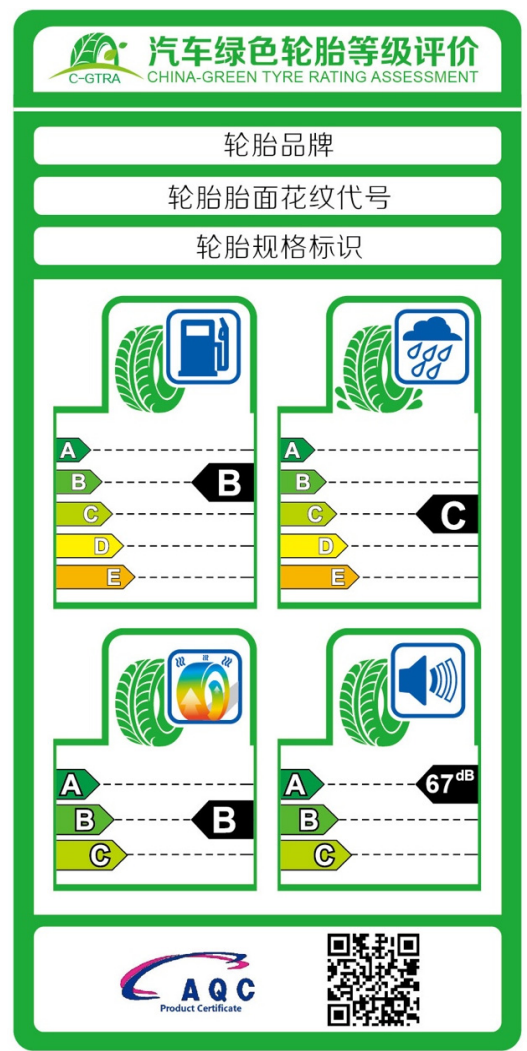

Fig. 24. China Green Tyre Rating Assessment (C-GTRA)

(source from Ren Min Wang, 2016 [76]; reprinted under fair use provision)

In the U.S., the National Highway Traffic Safety Administration (NHTSA) requires tire labeling according to the Uniform Tire Quality Grading standard (UTQG), including wet braking traction performance, predicted tread wear life, and high temperature endurance without tire noise requirements. The current federal regulation for traffic noise is 23 CFR 772 (2010) [78].

In Canada, the regulation regarding sound levels related to transportation is "Noise Assessment Criteria in Land Use Planning, LU-131" published by the Ontario Ministry of the Environment in October of 1997 [79].

In India, the noise pollution is also regulated by CPCB (2000) [80] and framed under the Environment Act 1986 [81], as shown in Table 1.

Most policies are focused on exterior vehicle noise (mostly as per the coast-by method at $7.5 \mathrm{~m}$ distance from the vehicle [82]), but for interior noise, they are only regulated by market requirement or consumer orientation (Mohamed, et al., 2013 [3]).

Table 1. Permissible limits on ambient noise standards in India (source from CPCB, 2000 [80]; reprinted under fair use provision)

\begin{tabular}{|c|c|c|c|}
\hline Zone code & Category of zone & Day $(6 \mathrm{am}$ to $10 \mathrm{pm})$ & Night $(10 \mathrm{pm}$ to $6 \mathrm{am})$ \\
\hline $\mathrm{A}$ & Industrial & $75 \mathrm{~dB}$ & $70 \mathrm{~dB}$ \\
\hline B & Commercial & $65 \mathrm{~dB}$ & $55 \mathrm{~dB}$ \\
\hline C & Residential & $55 \mathrm{~dB}$ & $45 \mathrm{~dB}$ \\
\hline D & Silent & $50 \mathrm{~dB}$ & $40 \mathrm{~dB}$ \\
\hline
\end{tabular}

\subsection{Other considerations}

Traffic noise is dependent on the traffic volume, traffic speed and percentage of trucks in the 
traffic mix [83] (on high-speed road, the dominant noise source is heavy truck tires [84]). In the US, federal Code 23, Section 772 (2010) [78] requires transportation projects that receive federal funding to meet noise impacts limits. The U.S. Department of Transportation, Federal Highway Administration (2010) [85] presented five approved methods to mitigate traffic noise, including noise barriers, vegetation screens, traffic management, building insulation and buffer zones, most of which are passive noise control regarding sound transmission path. Usually, the noise barrier is the only viable option to mitigate the traffic noise.

The reason why quiet pavement is not included in the approved methods is that pavements can wear out and become louder with time. Donovan et al. (2013) [86] presented a methodology for evaluating the feasibility, reasonableness, effectiveness, acoustic longevity, and economic features of pavement strategies and barriers for noise mitigation. The Life Cycle Cost Analysis (LCCA) is utilized to quantify their economic features. It was reported that noise barriers have a higher initial cost (\$1.3-3 million per mile [87]) than quieter pavements but have lower ongoing costs due to minimal maintenance requirements. In addition, the noise reduction effect of noise barriers does not diminish with time.

However, as the endurance of pavement acoustic performance improves, more and more transportation agencies are interested in quiet pavement, especially in Europe. Moreover, noise barriers have some disadvantages: locations such as hillsides and intersections are not suitable for building noise barriers; most noise barriers block the view, which does not look beautiful; barrier on one side will increase reflection to the other side (Kohler, 2010 [88]). Controlling tire-pavement interaction noise at its source, i.e., quiet pavement and quiet tire, can be a more economical and effective approach.

As electric and hybrid motor vehicles (E/H vehicles) gained increasing interest, a significant reduction (3-4 dB) of traffic noise emissions (Jabben et al., 2012 [89]) can be reached. On the other hand, concerns arise that $\mathrm{E} / \mathrm{H}$ vehicles with quiet pavements might pose a severe threat to the safety of vulnerable road users due to poor vehicle detection ability (Mendonça, 2013 [90]). Some regulations start to focus on limiting the minimum sound of electric vehicles. However, Sandberg (2013) [91] pointed out that it is currently far more justified to work towards reducing the noise emission of the noisiest vehicles than adding noise to the quiet ones.

\section{TPIN reduction approaches}

As traffic noise is expected to be more of an environmental and health concern, the exploration to reduce the noise, especially tire road noise, will be of greater interest (Bückers and Stöckert, 2012 [92]). A lot of attempts have been conducted to reduce tire-pavement interaction noise at the source and to ensure a lasting effect, such as low-noise tires and quite road (Sandberg, 2001 [11]). The pavement seems to have greater potential for noise reduction $(10 \mathrm{~dB})$ compared to tire $(4 \mathrm{~dB})$ at the speed of $60 \mathrm{mph}$ (Mogrovejo et al., 2014 [93]; Saemann et al., 2012 [94]). In the following, the approaches to tire pavement noise reductions are introduced.

\subsection{Quiet tire}

For a long time, it was assumed that a quiet tire was an unsafe tire for the general public. This assumption was based on the belief that quiet tires should be very smooth and consequently should have a low skid resistance (Heckl, 1986 [55]). As regulations for silent tires and vehicles are introduced internationally (Nijland et al., 2003 [75]), a number of design concepts to reduce tire noise are presented, as shown in Table 2. It can be seen that the modification has been applied to the tire tread, tread pattern, tire cavity, and rim. However, few of these design concepts are commercially viable due to manufacturing complexities and costs, safety and durability; the sound absorbing materials attached inside the tire cavity to reduce the cavity resonance noise might be the most successful so far. 
Table 2. Design concepts for quiet tire (green indicates commercially available)

\begin{tabular}{|c|c|c|c|c|c|c|}
\hline \\
\hline Category & Reference & $\begin{array}{l}\text { Company / } \\
\text { Institution }\end{array}$ & Modification & Method & $\begin{array}{c}\text { Reduction } \\
\text { effect }\end{array}$ & Illustration \\
\hline $\begin{array}{c}\text { Tread } \\
\text { vibration }\end{array}$ & $\begin{array}{c}\text { Iwao and } \\
\text { Yamazaki, } \\
1996 \text { [95] }\end{array}$ & $\begin{array}{c}\text { Nissan Motor } \\
\text { Co., Ltd. } \\
\text { (Japan) }\end{array}$ & Tire tread & $\begin{array}{c}\text { Attachment of a rubber } \\
\text { ring on the inside surface } \\
\text { of the center part of the } \\
\text { tread surface }\end{array}$ & $\begin{array}{c}5 \mathrm{~dB} \\
(800-1600 \mathrm{~Hz})\end{array}$ & Fig. 25 \\
\hline $\begin{array}{l}\text { Tread } \\
\text { vibration } \\
\& \text { cavity } \\
\text { resonance }\end{array}$ & $\begin{array}{c}\text { Saemann et } \\
\text { al., 2011 } \\
{[96]}\end{array}$ & \begin{tabular}{|} 
Continental \\
Reifen \\
Deutschland \\
GmbH \\
(Germany) \\
\end{tabular} & $\begin{array}{l}\text { Tire tread } \\
\text { and cavity }\end{array}$ & $\begin{array}{l}\text { Application of seal and } \\
\text { foam absorber to the } \\
\text { inside surface of tread } \\
\text { band }\end{array}$ & $\begin{array}{c}7.5 \mathrm{~dB} \\
(230-240 \mathrm{~Hz})\end{array}$ & Fig. 26 \\
\hline \multirow{4}{*}{$\begin{array}{l}\text { Air } \\
\text { pumping, } \\
\text { pipe } \\
\text { resonance }\end{array}$} & \begin{tabular}{|c|} 
Zhou, 2013 \\
[97]; Zhou \\
et al., 2014 \\
{$[98]$} \\
\end{tabular} & $\begin{array}{l}\text { Jiangsu } \\
\text { University } \\
\text { (China) }\end{array}$ & Tread pattern & $\begin{array}{c}\text { Reduction of fluid drag } \\
\text { force and noise by using } \\
\text { the bypass structure and } \\
\text { bionic tread groove }\end{array}$ & $\begin{array}{c}>10 \mathrm{~dB} \\
(800-1500 \mathrm{~Hz})\end{array}$ & Fig. 27 \\
\hline & $\begin{array}{l}\text { Kakumu, } \\
1990 \text { [99] }\end{array}$ & $\begin{array}{l}\text { Sumitomo } \\
\text { Rubber } \\
\text { Industries } \\
\text { (Japan) }\end{array}$ & Tread pattern & $\begin{array}{l}\text { Circumferential length of } \\
\text { contact patch is } \\
\text { substantially equal to the } \\
\text { transverse groove pitch } \\
\text { multiplied by an integer }\end{array}$ & $5 \mathrm{~dB}$ & Fig. 28 \\
\hline & $\begin{array}{l}\text { Cusimano, } \\
1992[100]\end{array}$ & $\begin{array}{c}\text { Bridgestone } / \mathrm{F} \\
\text { irestone, Inc. } \\
\text { (USA) }\end{array}$ & Tread pattern & $\begin{array}{c}\text { Strategic placement of } \\
\text { grooves such that the } \\
\text { amount of groove void } \\
\text { across the trailing and/or } \\
\text { leading edges of the } \\
\text { footprint is substantially } \\
\text { uniform about the } \\
\text { circumference of the tire }\end{array}$ & N/A & Fig. 29 \\
\hline & $\begin{array}{c}\text { Continental } \\
\mathrm{AG}, 2016 \\
{[101]}\end{array}$ & \begin{tabular}{|} 
Continental \\
Reifen \\
Deutschland \\
GmbH \\
(Germany)
\end{tabular} & Tread pattern & \begin{tabular}{|} 
(1) "Harmonic Comfort \\
Chambers" based on the \\
"Helmholtz resonator" \\
positioned on the inner \\
shoulder of the tire \\
pattern \\
(2) "0" dB-Eaters" \\
uniquely shaped \\
in-groove elements \\
designed to split and \\
diffuse noise waves for \\
lower road noise
\end{tabular} & N/A & Fig. 30 \\
\hline \multirow{3}{*}{$\begin{array}{c}\text { Cavity/rim } \\
\text { coupling } \\
\text { resonance }\end{array}$} & $\begin{array}{c}\text { Fitz and } \\
\text { Heck, 2001 } \\
\text { [102] }\end{array}$ & $\begin{array}{c}\text { Epilogics } \\
\text { Group (USA) }\end{array}$ & Rim & $\begin{array}{c}\text { Lightweight steel rim to } \\
\text { shift the modal } \\
\text { frequency of the tire rim } \\
\text { outside of } 200-250 \mathrm{~Hz}\end{array}$ & $\begin{array}{c}\text { Ineffective } \\
\text { (shift down } \\
1 \mathrm{~Hz} \text { ) }\end{array}$ & Fig. 31 \\
\hline & $\begin{array}{c}\text { Sainty et al., } \\
2012 \text { [103] }\end{array}$ & $\begin{array}{c}\text { RMIT } \\
\text { University } \\
\text { (Australia) }\end{array}$ & Tire tread & $\begin{array}{c}\text { Extrusion of three strips } \\
\text { of rubber from the tire } \\
\text { into the cavity to shift } \\
\text { the modal frequency of } \\
\text { the tire cavity }\end{array}$ & $\begin{array}{c}\text { Marginal } \\
\text { (shift down } \\
18 \mathrm{~Hz} \text { ) }\end{array}$ & Fig. 32 \\
\hline & $\begin{array}{c}\text { Sainty et al., } \\
2012 \text { [103] }\end{array}$ & $\begin{array}{c}\text { RMIT } \\
\text { University } \\
\text { (Australia) }\end{array}$ & $\begin{array}{l}\text { Rim and } \\
\text { cavity }\end{array}$ & \begin{tabular}{|c|} 
Attachment of elastic \\
ring on rim with \\
separator fins which \\
extends into the cavity \\
due to centrifugal forces
\end{tabular} & $\begin{array}{l}\text { Effective } \\
\text { (shift up } \\
156 \mathrm{~Hz} \text { ) }\end{array}$ & Fig. 33 \\
\hline
\end{tabular}




\begin{tabular}{|c|c|c|c|c|c|c|}
\hline \multirow{7}{*}{$\begin{array}{l}\text { Cavity } \\
\text { resonance }\end{array}$} & $\begin{array}{l}\text { Molisani et } \\
\text { al., 2003 } \\
\text { [43], [104] }\end{array}$ & \begin{tabular}{|} 
Virginia Tech \\
\& Michelin \\
North \\
America, Inc. \\
(USA) \\
\end{tabular} & Rim & $\begin{array}{c}\text { Incorporation of } \\
\text { secondary acoustic } \\
\text { cavities to detune and } \\
\text { damp out the main tire } \\
\text { cavity resonance }\end{array}$ & $\begin{array}{l}15 \mathrm{~dB} \text { force } \\
\text { transmission } \\
(230 \mathrm{~Hz})\end{array}$ & Fig. 34 \\
\hline & $\begin{array}{l}\text { Kamiyama, } \\
2014 \text { [105] }\end{array}$ & $\begin{array}{c}\text { Honda R\&D } \\
\text { Co. Ltd. } \\
\text { (Japan) }\end{array}$ & Rim & $\begin{array}{c}\text { Assembly of separate } \\
\text { thin, lightweight plastic } \\
\text { resonators in the wheel } \\
\text { well }\end{array}$ & $\begin{array}{c}10 \mathrm{~dB} \\
(190-230 \mathrm{~Hz})\end{array}$ & Fig. 35 \\
\hline & $\begin{array}{l}\text { Fernandez, } \\
2006[106]\end{array}$ & $\begin{array}{c}\text { KTH } \\
\text { University } \\
\text { (Sweden) } \\
\end{array}$ & Rim & $\begin{array}{c}\text { Implementation of a } \\
\text { Helmholtz resonator } \\
\text { attached to the rim }\end{array}$ & $\begin{array}{c}\text { Obvious } \\
(205-240 \mathrm{~Hz})\end{array}$ & Fig. 36 \\
\hline & $\begin{array}{l}\text { Sainty et al., } \\
2012[103]\end{array}$ & $\begin{array}{c}\text { RMIT } \\
\text { University } \\
\text { (Australia) }\end{array}$ & Cavity & $\begin{array}{c}\text { Introduction of a sound } \\
\text { absorption material }\end{array}$ & $\begin{array}{c}14 \mathrm{~dB} \\
(225 \mathrm{~Hz})\end{array}$ & Fig. 37 \\
\hline & $\begin{array}{c}\text { Yukawa et } \\
\text { al., 2004 } \\
{[107]}\end{array}$ & $\begin{array}{l}\text { Sumitomo } \\
\text { Rubber } \\
\text { Industries } \\
\text { (Japan) }\end{array}$ & Cavity & $\begin{array}{c}\text { Gluing of a foam layer to } \\
\text { the inner liner beneath } \\
\text { the tread }\end{array}$ & $\begin{array}{c}\text { Obvious } \\
\text { (interior noise) }\end{array}$ & Fig. 38 \\
\hline & $\begin{array}{c}\text { Pirelli, } 2013 \\
{[108]}\end{array}$ & $\begin{array}{l}\text { Pirelli \& C. } \\
\text { SpA (Italy) }\end{array}$ & Cavity & $\begin{array}{l}\text { Pirelli Noise Cancelling } \\
\text { System (PNCS, P } \\
\text { ZEROTM): polyurethane }_{\text {sponge inserted into the }} \\
\text { cavity to absorb the } \\
\text { vibrations }\end{array}$ & $2-3 \mathrm{~dB}$ & Fig. 39 \\
\hline & \begin{tabular}{|l} 
Mohamed \\
and Wang, \\
2015 [109]
\end{tabular} & $\begin{array}{c}\text { RMIT } \\
\text { University } \\
\text { (Australia) }\end{array}$ & Tire & $\begin{array}{c}\text { Placing a trim layer onto } \\
\text { the inner surface of the } \\
\text { tire tread }\end{array}$ & $\begin{array}{c}10 \mathrm{~dB} \\
(225 \mathrm{~Hz})\end{array}$ & Fig. 40 \\
\hline
\end{tabular}

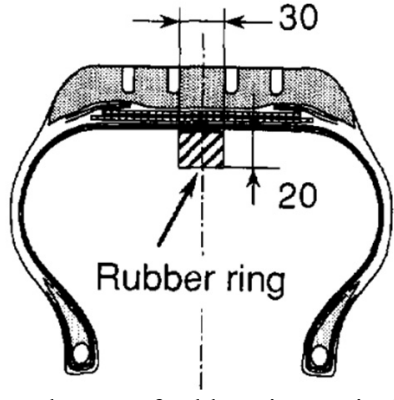

Fig. 25. Attachment of rubber ring on inside surface of center part of tread surface (source from Iwao and Yamazaki, 1996 [95], Fig. 13; reprinted under fair use provision)

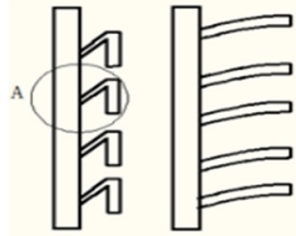

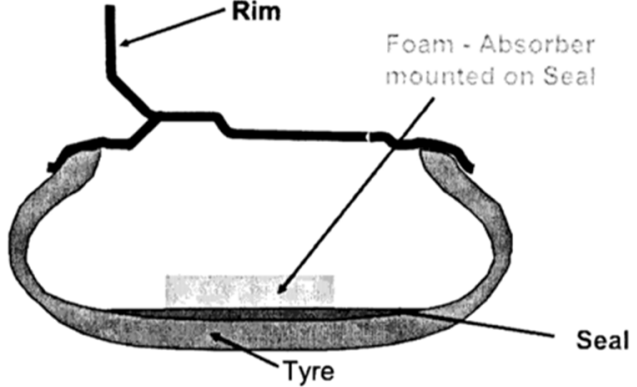

Fig. 26. Tire cross section with seal and foam absorber mounted on rim (source from Saemann et al., 2011 [96], Fig. 1; reprinted under fair use provision)

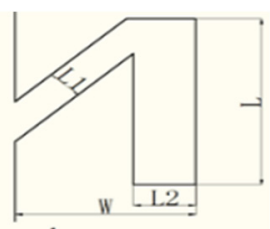

A

Fig. 27. Reduction of fluid drag force and noise by using bypass structure and bionic tread groove (source from Zhou et al., 2014 [98], Fig. 4; reprinted under fair use provision) 


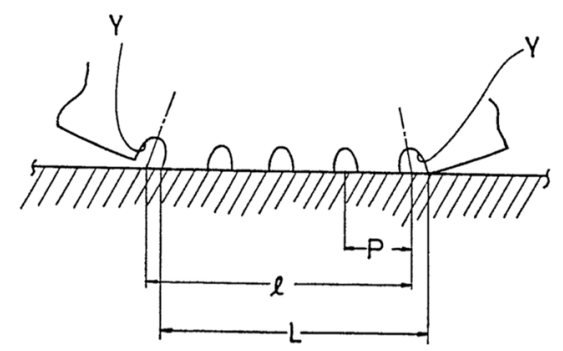

Fig. 28. Illustration of low noise transverse groove $(L=4 \times P)$ (source from Kakumu, 1990 [99], Fig. 2; reprinted under fair use provision)

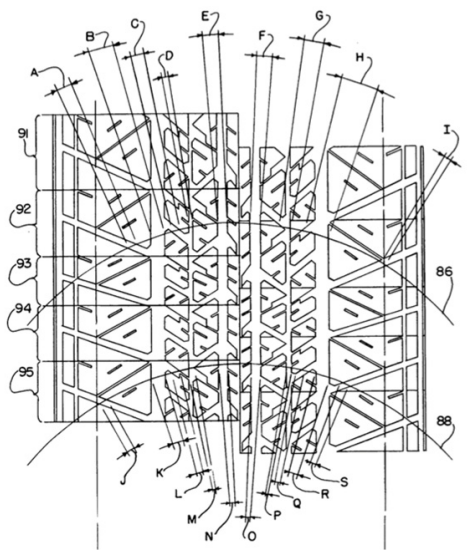

Fig. 29. Illustration of low noise tread pattern (The sum of the groove void $(A+B+C+D+E+F+G+H+1)$ along projection 86 is substantially equal to the sum of groove void $(\mathrm{J}+\mathrm{K}+\mathrm{L}+\mathrm{M}+\mathrm{N}+\mathrm{O}+\mathrm{P}+\mathrm{Q}+\mathrm{R}+\mathrm{S})$ along projection 88) (Source from Cusimano, 1992 [100], Fig. 1A; reprinted under fair use provision)

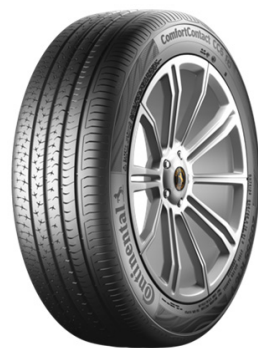

a)

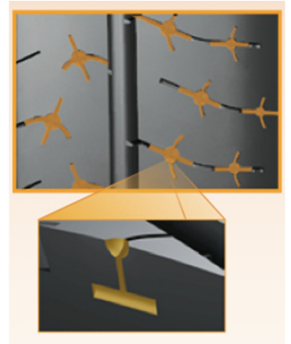

b)

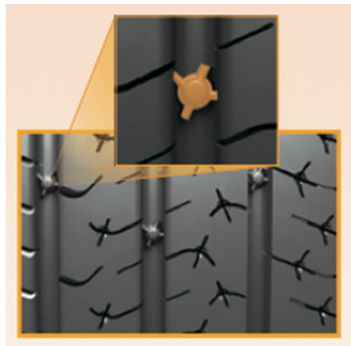

c)

Fig. 30. a) product image of Continental ComfortContact CC6, b) harmonic comfort chambers, c) 0' dB-Eaters (Source from Continental AG, 2016 [101]; reprinted under fair use provision)

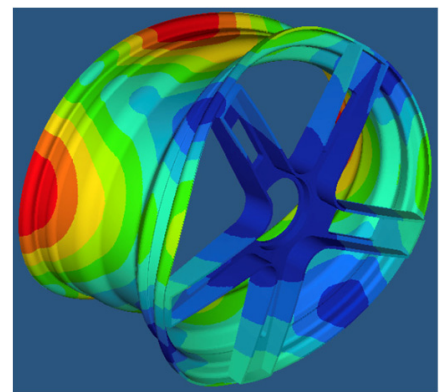

Fig. 31. Finite element displacement analysis results for Kühl wheel mode shape at $210 \mathrm{~Hz}$ (source from Sainty et al., 2012 [103], Fig. 2; reprinted with permission from ASME) 


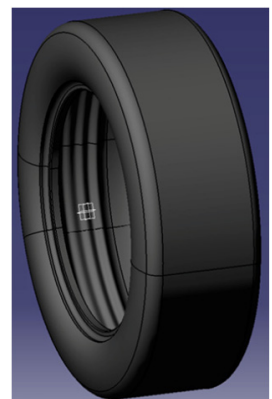

Fig. 32. CAD model of tire with three rubber strips extruded into cavity (source from

Sainty et al., 2012 [103], Fig. 6; reprinted with permission from ASME)

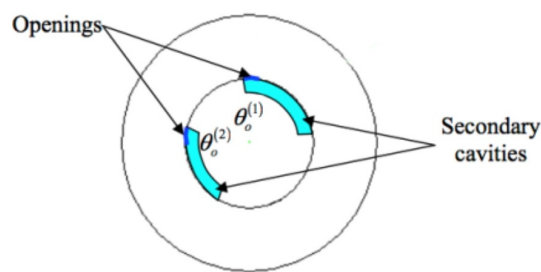

a)

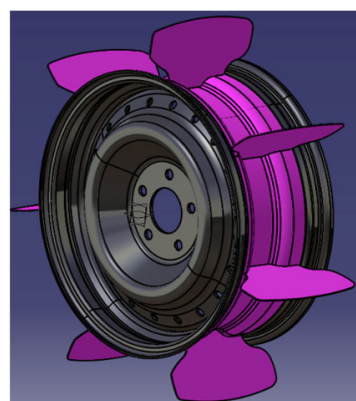

Fig. 33. CAD model of proposed elastic ring with four fins attached (source from Sainty et al., 2012 [103], Fig. 10; reprinted with permission from ASME)

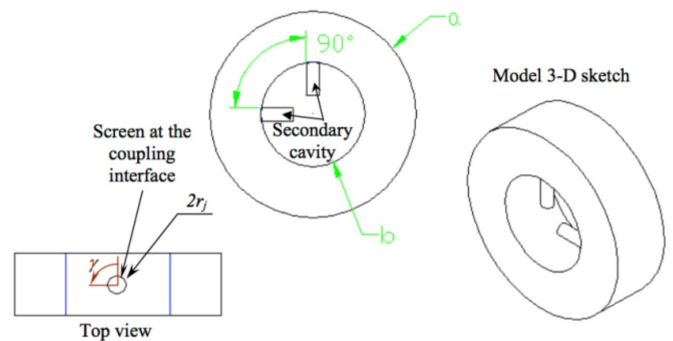

b)

Fig. 34. Incorporation of secondary acoustic cavities to detune and damp out main tire cavity resonance (source from Molisani, 2004 [104], Fig. 42; reprinted under fair use provision)

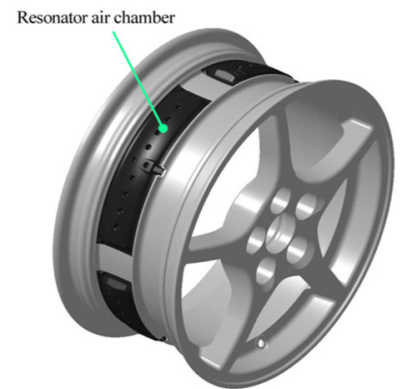

Fig. 35. Assembly of separate thin, lightweight plastic resonators in wheel well (source from Kamiyama, 2014 [105], Fig. 1; reprinted under fair use provision)

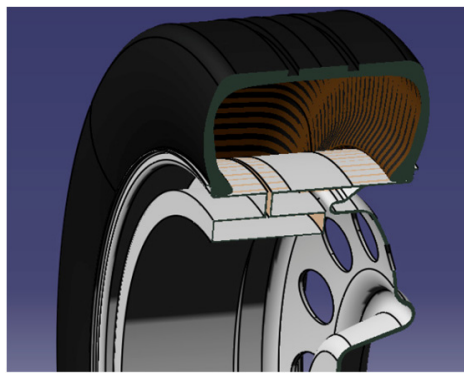

Fig. 36. CAD model fitted with Helmholtz resonator (source from Sainty et al., 2012 [103],

Fig. 4; reprinted with permission from ASME)

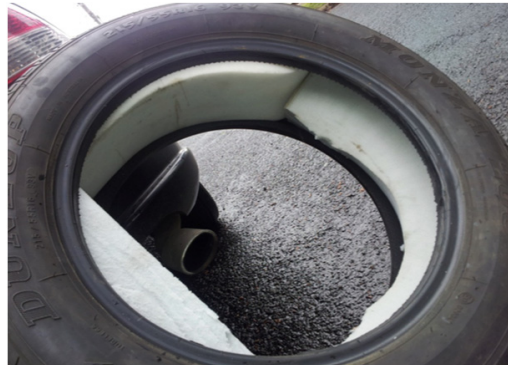

Fig. 37. Testing tire filled with PU foam prior to wheel rim and tire assembling (source from Sainty et al., 2012 [103], Fig. 7; reprinted with permission from ASME) 


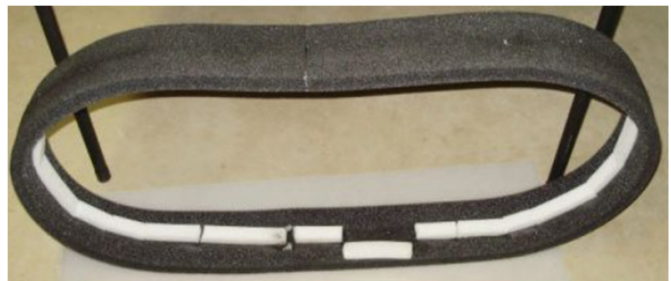

Fig. 38. Tire Silencer with white rigid foam support removed from tire after 1,053 miles

(source from Schmidt and Majumdar, 2011 [110],

Fig. 2; reprinted under fair use provision)

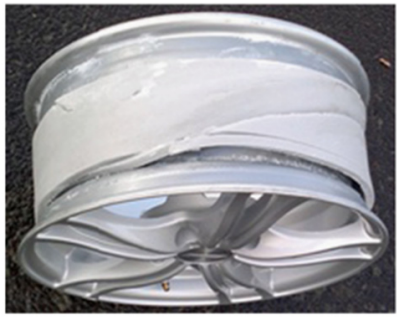

a)

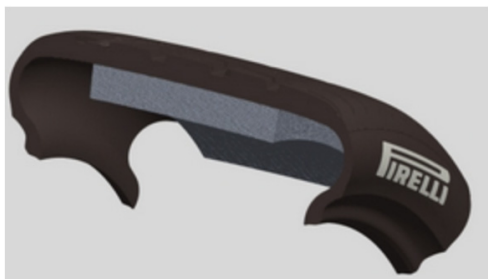

Fig. 39. Pirelli Noise Cancelling System (PNCS) (source from Tire Business, 2013 [111]; reprinted under fair use provision)

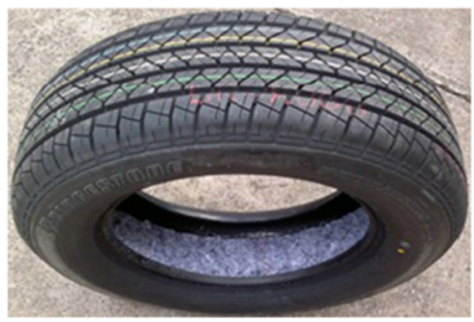

b)

Fig. 40. Installation of trim onto rim and tire: a) trim layer on rim; b) trim layer onto tire (source from Mohamed and Wang, 2015 [109], Fig. 7; reprinted with permission from Elsevier)

In the tire industry, the tread pattern design and pitch sequence optimization have been extensively investigated to spread the noise spectrum to a broader band, so that the noise will sound less objectionable. Morgan (2002) [112] optimized a three-pitch sequence where the relative length of the shortest pitch $(\mathrm{S})$ is 0.8 , the medium pitch $(M)$ is 1.0 , and the longest pitch $(L)$ is 1.2. 100 pitch sequences were proposed and the acoustically preferred one is LMSMSLMLMLMLMLMMLMLMLMLMLM. However, very few achievements have been published after 1980's due to commercial considerations (Hoffmeister and Bernard, 1998 [113]). In academia, without the availability of the tire building machine and mold, it is very difficult or nearly impossible for researchers to modify the tread pattern or investigate its effect on tire noise $[114,115]$. However, academic researchers still made numerous attempts to reveal the tire noise generation mechanisms by looking into the tire vibration modes. To reduce the noise relating to certain modes, there are generally two ways (Aboutorabi and Kung, 2012 [116]): (1) the modal frequency shifted to where the noise was less likely to be amplified or transferred; (2) more damping introduced into the tire, for example, to decrease the rubber hardness or stiffness [117].

During the tire design process, a lot of parameters have contradictory effects on tire parameters, and compromises and optimizations are needed to achieve vehicle performances such as traction, rolling resistance, durability, ride comfort, noise, wear resistance, etc. (Lee et al., 2011 [118]), as shown in Fig. 41, Fig. 42 and Table 3.

However, there seems to be no consistent conflict between noise characteristics and friction, rolling resistance, wet braking or aquaplaning speed after examining about 100 modern car tires of similar size (Sandberg et al., 1998 [119]; Sandberg and Ejsmont, 2000 [120]). On the contrary, the noise reduction can meantime also lead to the reduction of rolling resistance and possible improvement of friction characteristics. Low noise tread pattern design includes pattern randomization, ventilating channels, reducing the air/rubber ratio (to $20 \%$ from today's common value $30 \%$ [69]), increasing the number of circumferential tread elements preferably up to 100 (common is 65), increasing number of sipes, or optimizing tread element pitch sequence (Kim et al., 2012 [121]), most of which are also favorable to hydroplaning performance. 


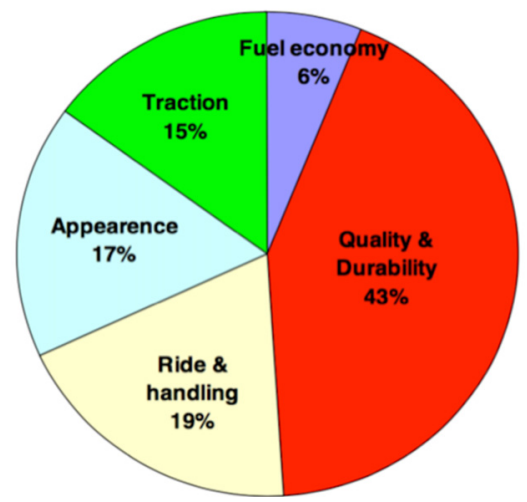

Fig. 41. Criteria for choice of tires by consumers

(source from FEHRL, 2001 [69], Fig. 49; reprinted under fair use provision)

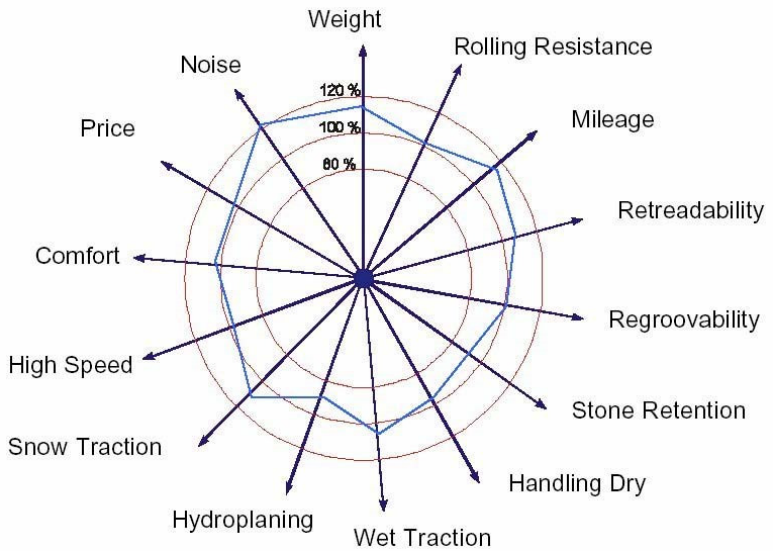

Fig. 42. Polar diagram illustrating the property profile of particular tire (source from FEHRL, 2001 [69],

Fig. 26, kindly obtained from Dr. Saemann, Continental Tyres; reprinted under fair use provision)

Table 3. Target conflicts in tire development (-1 indicates bad; 1 indicates good; 0 indicates ambiguous) (modified from FEHRL, 2001 [69])

\begin{tabular}{|c|c|c|c|c|c|c|c|c|}
\hline \multirow{3}{*}{ Performance } & \multicolumn{4}{|c|}{ Tread } & \multicolumn{4}{c|}{ Construction } \\
\cline { 2 - 9 } & \multicolumn{2}{|c|}{ Compound } & \multicolumn{2}{c|}{ Design } & \multicolumn{2}{c|}{ Footprint } & \multicolumn{2}{c|}{ Sidewall } \\
\cline { 2 - 9 } & Stiffness & Damping & $\begin{array}{c}\text { Increasing } \\
\text { block size }\end{array}$ & $\begin{array}{c}\text { Increasing } \\
\text { number of sipes }\end{array}$ & Round & Squared & Stiff & Soft \\
\hline Winter (snow) & -1 & 1 & -1 & 1 & 1 & 0 & 0 & 0 \\
\hline Noise & -1 & 1 & -1 & 1 & 0 & 0 & -1 & 1 \\
\hline Wet grip & -1 & 1 & 0 & 1 & -1 & 1 & 1 & 0 \\
\hline Handling & 1 & 0 & 1 & -1 & 0 & 0 & 1 & -1 \\
\hline Dry braking & 1 & 1 & 1 & -1 & -1 & 1 & 1 & -1 \\
\hline Aquaplaning & 1 & 0 & -1 & 0 & 1 & 0 & 1 & 0 \\
\hline Rolling & 0 & -1 & 0 & -1 & -1 & 1 & 0 & -1 \\
resistance & 0 & 1 & 1 & 1 & -1 & 1 & 1 & 1 \\
\hline Mileage & 0 & -1 & 0 & -1 & & 1 & 0 & 0 \\
\hline Endurance & 0 & -1 & -1 & -1 & -1 & 1 & 0 & 0 \\
\hline High speed & 0 & -1 & 1 & -1 & 0 & 0 & 0 & 0 \\
\hline Heat build-up & 0 & 0 & 0 & 0 & 1 & 0 & -1 & 1 \\
\hline Comfort (NVH) & 0 & 0 & 0 & 0 & 0 & 0 & 1 & -1 \\
\hline Flat spot & 0 & 0 & \multicolumn{7}{|c|}{} \\
\hline
\end{tabular}


There is also no strong evidence showing tradeoff between low noise emission and high safety either, although there is a common prejudice that low noise tire will sacrifice safety (Sandberg, 2001 [11]). It was also shown that the low noise technology could be adapted to run flat tires (FEHRL, 2001 [69]). In general, the tires on the market with high safety show characteristics of high noise, just statistically $\left(R^{2}=0.29\right)$, but not deterministically (Nelson et al., 1993 [122]; FEHRL, 2001 [69]).

There is no denying that the modifications for noise reduction might influence other tire performances. Saemann et al. (2012) [94] presented that lowering the sound level by $3 \mathrm{~dB}$ might result in several drawbacks associated with other performance, as listed in Table 4.

Table 4. Modifications to lower tire noise and drawbacks (Saemann et al., 2012 [94])

\begin{tabular}{|c|c|c|}
\hline Parameter & Modification & Influence \\
\hline $\begin{array}{l}\text { Tread } \\
\text { pattern }\end{array}$ & From $34 \%$ void volume to slick & $\begin{array}{c}\text { Increase in wet braking by } \\
40 \% \\
\text { Increase in aquaplaning in } \\
\text { curve by } 60 \%\end{array}$ \\
\hline $\begin{array}{c}\text { Tread } \\
\text { material }\end{array}$ & $\begin{array}{l}\text { From summer tread compound to ice tread compound } \\
\text { (decrease rubber hardness/stiffness) }\end{array}$ & Increase in wear by $50 \%$ \\
\hline $\begin{array}{c}\text { Tread } \\
\text { material }\end{array}$ & $\begin{array}{c}\text { From normal tread to thicker under tread } \\
\text { (decrease contact stiffness) }\end{array}$ & $\begin{array}{l}\text { Increase in rolling } \\
\text { resistance by } 15 \%\end{array}$ \\
\hline Carcass & $\begin{array}{c}\text { Increase belt stiffness (such as increasing the number of } \\
\text { the plies, adding reinforcement rubber, } \\
\text { and using steel ply materials) }\end{array}$ & $\begin{array}{l}\text { Decrease in wear by } 20 \% \\
\text { Increase in cornering } \\
\text { power by } 10 \%\end{array}$ \\
\hline
\end{tabular}

Major tire companies also produce quiet tires, such as Goodyear Assurance ComforTred, Hankook Optimo H727, Hankook Ventus S1 evo² SUV (foam attached on the inside of tire tread), Yokohama "dB-tyre", Michelin Primacy LC, Michelin Defender, Michelin Primacy MXV4, Michelin Energy Saver A/S, and Michelin Primacy 3 ST.

\subsection{Quiet pavement}

For the same driving conditions, there can be as much as a 9 dBA difference for a single pavement type and as much as a $14 \mathrm{dBA}$ difference between different types of pavement (Bernhard and Wayson, 2005 [24]). There are some suggestions on noise reduction in terms of pavement characteristics, listed in Table 5.

Table 5. General suggestions on noise reduction in terms of pavement characteristics (Rasmussen, 2010 [123])

\begin{tabular}{|c|c|}
\hline Parameter & Suggestion \\
\hline \multirow{3}{*}{ Texture } & $\begin{array}{l}\text { Avoid (flatten) texture at intervals }>1 \text { inch or smooth (floated or polished) surfaces to } \\
\text { allow air escape channels }\end{array}$ \\
\hline & Negative texture (grooves, without fins) \\
\hline & Texture oriented longitudinally; if transverse, should be closely spaced and randomized \\
\hline \multirow[b]{2}{*}{ Concrete } & Strong and durable mortar; mix optimized for placement, finishing, curing \\
\hline & $\begin{array}{l}\text { Siliceous sands for durability and friction (hard, durable, and polish resistant coarse } \\
\text { aggregate for diamond grinding; adequate and consistent depth of mortar near the surface } \\
\text { for tined and drag textures) }\end{array}$ \\
\hline \multirow{2}{*}{ Joints } & Narrow, single-cut joints preferred but avoid widened (reservoir) cuts \\
\hline & Avoid faulted or spalled joints; design or retrofit adequate load transfer \\
\hline \multirow{2}{*}{ Aggregate } & Increase the porosity (porous asphalt, over $20 \%$ ) and depth of the porous layer \\
\hline & Decrease pavement stiffness (elastic pavement) \\
\hline
\end{tabular}

A couple of pavements are reported to be quiet pavement or have potential to be, as displayed in Table 6. 
In addition, there are some other novelty pavement designs, but further investigation and validation may be needed. Hofman and Kooij (2003) [128] demonstrated a three-layer design: the top two layers were assembled as one roll-up layer with a thickness of $30 \mathrm{~mm}$, and the bottom support layer had cavities as Helmholtz resonators. Maennel et al. (2013) [129] presented a similar Helmholtz type porous asphalt, as illustrated in Fig. 43. A noise attenuation of $3 \mathrm{~dB}$ was found compared to the twin layered porous asphalt and it also had good acoustic durability.

Table 6. Quiet pavement technologies (McGhee, 2012 [124]; Mogrovejo et al., 2014 [93])

\begin{tabular}{|c|c|}
\hline Category & Technology \\
\hline \multirow{5}{*}{$\begin{array}{l}\text { Asphalt } \\
\text { concrete }\end{array}$} & Rubberized Asphalt Concrete (RAC) [125] \\
\hline & $\begin{array}{l}\text { Polymer-Modified Asphalt Concrete (PMAC) or } \\
\text { Fiber-Modified Asphalt Concrete (FMAC) }\end{array}$ \\
\hline & Porous friction course surfaces with and without rubber \\
\hline & $\begin{array}{l}\text { Open-graded asphalt with small aggregate size and porosity over } 20 \% \\
\text { (reported to be quietest pavement currently in use) }\end{array}$ \\
\hline & Poroelastic Road Surface (PERS) \\
\hline \multirow[b]{3}{*}{$\begin{array}{l}\text { Cement } \\
\text { concrete }\end{array}$} & Conventional Diamond Grind (CDG) \\
\hline & Next Generation Concrete Surface (NGCS) \\
\hline & $\begin{array}{c}\text { Surface modification of Portland Cement Concretes (PCC) by introducing } 15-20 \% \\
\text { porosity: (1) through non-aggregate component of the mixture, resulting in Enhanced } \\
\text { Porosity Concrete (EPC); (2) through the use of soft inclusions (cellulose fibers) in the } \\
\text { matrix, resulting in Cellulose-Cement Composites (Neithalath, } 2004 \text { [126]; } \\
\text { Neithalath et al., } 2005[127])\end{array}$ \\
\hline
\end{tabular}

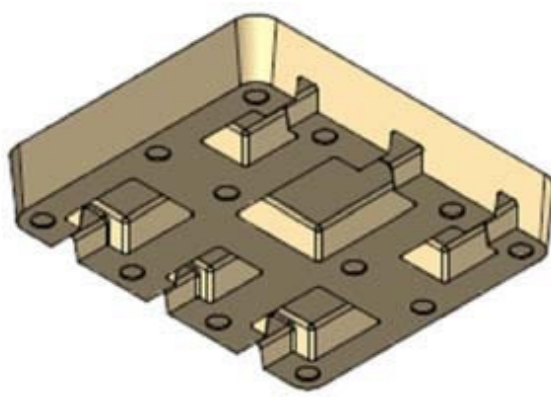

a)

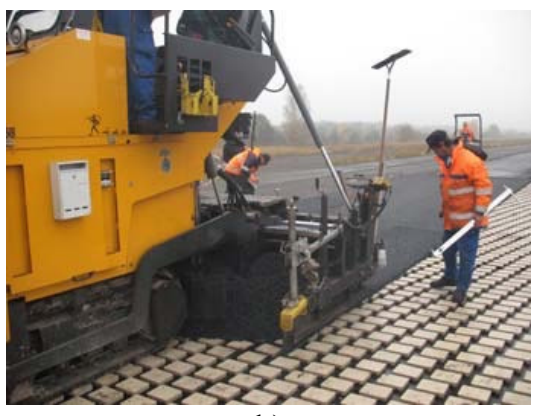

b)

Fig. 43. a) Helmholtz type porous asphalt, b) laying process (source from Maennel et al. (2013) [129], Fig. 7, Fig. 8; reprinted with permission from Mr. Manuel Männel of Müller-BBM GmbH, Germany)

For the quiet concrete pavements, Next Generation Concrete Surface (NGCS) can be the most important. The NGCS is basically made by the Conventional Diamond Grind (CDG) followed by a flush-grind operation and a longitudinal grooving step (Mogrovejo et al., 2014 [93]). It is a consistent, predictable, and quiet nonporous concrete texture with good lateral stability and hydroplaning resistance.

For the quiet asphalt concrete pavements, Poroelastic Road Surface (PERS) can be the most promising (Nilsson and Zetterling, 1990 [130]). It is a wearing course with a very high porosity $(>20 \%)$ and high proportion of rubber or epoxy ( $>20 \%$ in weight) either in the shape of granules or elongated fiber-like particles (Sandberg and Goubert, 2011 [131]). It was claimed that it was $10 \mathrm{dBA}$ quieter than conventional pavements. Noise attenuation is likely to occur for almost all noise mechanisms on PERS, such as low texture impact due to aggregate of small maximum size and small stiffness, low air pumping and high absorption due to high void content, low stick/slip and stick/snap motions due to rubber/rubber contact. It is also expected to have good traction and wet skid resistance properties. However, nearly all field tests so far have failed in some way or another, such as bad durability, even though it has been brought up by Nilsson around 40 years 
ago (Nilsson, 1979 [132]), indicating that further improvements are necessary. For example, PERS increased the tire rolling resistance, which decreased the fuel economy.

\subsection{Combination of tires and pavements}

The contributions on noise reduction from tires and pavements cannot be considered separately [133]. A "quiet tire" on one specific pavement may not be quiet on the other type of pavements; similarly, a "quiet pavement" may not work for all the tires, which makes sense because TPIN comes from the interaction between the tire and pavement. The noise performance cannot be determined if only the tire or pavement information is given.

Fong (1998) [134] reported that the crossply truck tire (7.00R15) for medium trucks was among the noisiest over a relatively coarse chipseal pavement, but it was one of the quietest on a smoother chipseal pavement. Blokland and Leeuwen (2010) [135] investigated more than 2000 tire/road combinations and found that the sound reduction due to the combination of silent surfaces and silent tires was smaller than the numeric sum of both, especially for rough pavements where the silencing effects of quiet tires were marginal. Berge and Haukland (2011) [136] indicated that the Bridgestone B-250 had a relatively high type approval level (73 dBA) but was more silent on the Norwegian dense (and rough) surfaces than some other tires. The Michelin Energy Saver was rated as a quiet tire in terms of interior noise but was shown to be rather noisy in the exterior.

However, Berge and Haukland (2011) [136] also demonstrated that some tires seemed to perform as low-noise tires independent of the type of pavements.

\subsection{Active noise control}

Couche and Fuller (1998) [137] applied the Active Noise Control (ANC) for cabin noise from power train (40-500 Hz) with advanced speakers. Sun et al. (2012) [138] applied active noise control to the low-frequency structure-borne vehicle interior noise from tire road interaction and proved its efficiency. Zafeiropoulos et al. (2015) [139] investigated the active control of structure-borne interior noise based on the separation of front and rear structural noise related dynamics. However, the present author found no literature investigating the active noise control of exterior noise.

\section{Conclusions}

Due to the pressure from the regulations and customers, the tire/automotive companies and pavement organizations have been endeavoring to reduce the tire-pavement interaction noise. Tire industries attempted to optimize the tread pattern and tire construction for quieter tires, including pitch sequencing, tire cavity foam, tread and rim modifications, etc. Pavement industries attempted to modify the pavement texture and stiffness for quieter pavement. In the future, more and more research should be focused on the interaction between tire and pavement, which would lead to a quieter combination rather than quiet tire and quiet pavement separately. The challenge for both tire and pavement industries is that the acoustic performance of tire and pavement usually conflicts with other performances, such as traction, handling, rolling resistance, hydroplaning, and durability. Therefore, a compromise between noise reduction and maintaining other performances should be carefully considered and designed.

\section{Acknowledgements}

This study (Project Code: MODL-2015-B3-8) has been partially supported by the Center for Tire Research (CenTiRe), an NSF-I/UCRC (Industry/University Cooperative Research Centers) program led by Virginia Tech. The author hereby wishes to thank the project mentors and the members of the industrial advisory board (IAB) of CenTiRe for their kind support and guidance. The author is also very grateful for the advisement of his academic advisors, Dr. Ricardo Burdisso 
and Dr. Corina Sandu.

\section{References}

[1] Sandberg U., Ejsmont J. A. Tyre/Road Noise Reference Book. Informex, Sweden, 2002.

[2] Li T., Burdisso R., Sandu C. Literature review of models on tire-pavement interaction noise. Journal of Sound and Vibration, Vol. 420, 2018, p. 357-445.

[3] Mohamed Z., Wang X., Jazar R. A survey of wheel tyre cavity resonance noise. International Journal of Vehicle Noise and Vibration, Vol. 9, Issues 3-4, 2013, p. 276-293.

[4] Braun M. E., Walsh S. J., Horner J. L., Chuter R. Noise source characteristics in the ISO 362 vehicle pass-by noise test: literature review. Applied Acoustics, Vol. 74, Issue 11, 2013, p. 1241-1265.

[5] Robert Bosch GmbH, Automotive Handbook. 6th ed., SAE, 2004.

[6] Fry J., Jennings P., Taylor N., Jackson P. Vehicle drive-by noise prediction: a neural networks approach. SAE Technical Paper Series 1999-01-1740, 1999.

[7] Biermann J.-W. Noise Characteristics of Vehicles. Lecture notes, Institute for vehicles at RWTH Aachen University, Aachen, 2004, (in German).

[8] Zeller P. Handbook Vehicle Acoustic. Vieweg+Teubner Verlag, 2009, (in German).

[9] Alfredson R., Davies P. The radiation of sound from an engine exhaust. Journal of Sound and Vibration, Vol. 13, 1970, p. 389-408.

[10] Guide to State Highway Road Surface Noise. NZ Transport Agency, 2014.

[11] Sandberg U. Tyre/road noise - myths and realities. International Congress and Exhibition on Noise Control Engineering, 2001.

[12] Yang D., Wang Z., Li B., Luo Y., Lian X. Quantitative measurement of pass-by noise radiated by vehicles running at high speeds. Journal of Sound and Vibration, Vol. 330, Issue 7, 2011, p. 1352-1364.

[13] Bravo T., Ibarra D., Cobo P., Ibarra D. Extrapolation of maximum noise levels from near-field measurements to far-field positions. American Society of Mechanical Engineers, Noise Control and Acoustics Division (Publication) NCAD, Vol. 12, 2012, p. 10337-10348.

[14] Saemann E.-U. Holistic approach for rolling sound mitigation. 41st International Congress and Exposition on Noise Control Engineering, Vol. 10, 2012, p. 8275-8286.

[15] Donavan P. R. Investigations of the influence of lower frequency aerodynamic noise on interior cruise and exterior pass-by sound levels. SAE Technical Papers, 2012.

[16] Freeman T., Cerrato G. Vehicle pass-by noise estimations for component-level design. SAE Technical Papers, 2011.

[17] Dubois G., Cesbron J., Yin H. P., Anfosso Ledee F., Duhamel D. Statistical estimation of low frequency tyre/road noise from numerical contact forces. Applied Acoustics, Vol. 74, Issue 9, 2013, p. 1085-1093.

[18] Rasmussen R. O., Bernhard R. J., Sandberg U., Mun E. P. The Little Book of Quieter Pavements. Report No. FHWA-IF-08-004, 2007.

[19] Li T., Feng J., Burdisso R., Sandu C. The effects of speed on tire-pavement interaction noise (tread-pattern-related noise and non-tread-pattern-related noise). 35th Annual Meeting and Conference on Tire Science and Technology, Akron, Ohio, USA, 2016.

[20] Domenichini L., Fracassa A., La Torre F., Loprencipe G., Ranzo A., Scalamandrè A. Relationship between road surface characteristics and noise emission. First International Colloquium on Vehicle Tyre Road Interaction, Rome, Italy, 1999, p. 1-22.

[21] Dechipre H., Hartmann M., Ewert R., Delfs J. W. Assessment of numerical methods for computation of automotive rain gutter wind noise. 16th AIAA/CEAS Aeroacoustics Conference, Vol. 1, 2010, p. 835-847.

[22] Sandberg U. Noise emissions of road vehicles effect of regulations: Final Report 01-1. Noise News International, Vol. 9, Issue 3, 2001, p. 147-203.

[23] Gasparoni S., Czuka M., Kriegisch M., Wehr R., Conter M., Haider M. Controlled-pass-by measurements of electric vehicles within the Forever project. Proceedings of Forum Acusticum, 2014.

[24] Bernhard R. J., Wayson R. L., Haddock J. E., Neithalath N., El Aassar A., Olek J., Pellinen T. K., Weiss W. J. An Introduction to Tire/Pavement Noise of Asphalt Pavement, 2005.

[25] Schuhmacher A. Blind source separation applied to indoor vehicle pass-by measurements. SAE International Journal of Passenger Cars - Mechanical Systems, Vol. 8, Issue 3, 2015, p. 1034-1041. 
[26] He J., Jin X., Wang W., Jianfeng H., Xiaoxiong J., Wanying W. Analysis of tire tread pattern's impact on interior vibration and noise based on wavelet transform. Applied Mechanics and Materials, Vol. 66, Issues 68-3, 2011, p. 1755-1761.

[27] Chang J., Wanying W., Xiaoxiong J., Jin C., Wang W. Y., Jin X. X., Chang J., Wanying W., Xiaoxiong J. Study on tire noise transfer path identification. 10th International Conference on Signal Processing Proceedings, 2010, p. 2629-2632.

[28] Jen M. U., Lu M.-H. Effects of vehicle suspension characteristics on road-induced interior noise. 36th International Congress and Exhibition on Noise Control Engineering, Vol. 2, 2007, p. 1056-1065.

[29] Lim C.-S., Han E., Apelian C., Bogema D. A study on north American customer preference to interior noise using sound balance analysis. SAE International Journal of Passenger Cars - Mechanical Systems, Vol. 7, Issue 1, 2014, p. 32-40.

[30] Aissaoui A., Tupake R. S., Bijwe V., Meskine M., Perot F., Belanger A., Vaidya R. J. Flow-induced noise optimization of SUV HVAC system using a lattice Boltzmann method. SAE International Journal of Passenger Cars - Mechanical Systems, Vol. 8, Issue 3, 2015, p. 1053-1062.

[31] Nykänen A. Methods for Product Sound Design. Ph.D. Thesis, Division of Sound and Vibration, Luleå University of Technology, Luleå, 2008.

[32] Lopez I., Blom R. E. A., Roozen N. B., Nijmeijer H. Modelling vibrations on deformed rolling tyres - a modal approach. Journal of Sound and Vibration, Vol. 307, Issues 3-5, 2007, p. 481-494.

[33] Kitahara A., Akashi T., Waki Y., Heguri H., Warning N., Copyright C. Interior noise reduction by tire surface geometry and Helmholtz resonators on tread patterns. 40th International Congress and Exposition on Noise Control Engineering, Vol. 1, 2011, p. 608-613.

[34] Tsuji H., Maruyama S., Onishi K. Reciprocal measurements of the vehicle transfer function for road noise. SAE Technical Paper 2015-01-2241, 2015.

[35] Zhao T. Vehicle Interior Noise Identification and Control Based on Transfer Path Analysis. Jilin University, China, 2008.

[36] Saguchi T., Yumii K., Zakelj P. Vehicle interior noise prediction using tire characteristics and vehicle transmissibility. SAE Technical Papers, 2007.

[37] Kido I., Ueyama S. Coupled vibration analysis of tire and wheel for road noise improvement. SAE Technical Papers, 2005.

[38] Geluk T., Van Der Linden P., Vige D., Caudano M., Gottardi S., Ciraolo F., Mir H. Noise contribution analysis at suspension interfaces using different force identification techniques. SAE Technical Papers, 2011.

[39] Bekke D. A., Wijnant Y. H., De Boer A. Experimental review on interior tire-road noise models. Proceedings of ISMA - International Conference on Noise and Vibration Engineering, including USD, 2010, p. 3953-3960.

[40] Sottek R., Philippen B. Separation of airborne and structure-borne tire-road noise based on vehicle interior noise measurements. SAE Technical Papers, 2010.

[41] Sottek R., Philippen B. Tire-road noise analysis of on-road measurements under dynamic driving conditions. SAE Technical Papers, 2012.

[42] Pietrzyk A. Prediction of the dynamic response of a tire. International Congress and Exhibition on Noise Control Engineering, The Hague, The Netherlands, 2001.

[43] Molisani L. R., Burdisso R. A., Tsihlas D. A coupled tire structure/acoustic cavity model. International Journal of Solids and Structures, Vol. 40, Issue 19, 2003, p. 5125-5138.

[44] Fischer J., Behrendt M., Lieske D., Albers A. Measurement and analysis of the interior noise and the transfer path of acoustic phenomena into the driver cabin of a battery electric vehicle. Inter-Noise, 2014.

[45] Sung S. H., Nefske D. J., Feldmaier D. A. A structural-acoustic finite element method for predicting automotive vehicle interior road noise. ASME International Mechanical Engineering Congress and Exposition, Vol. 15, 2010, p. 527-534.

[46] Sung S. H., Nefske D. J. A statistical regression-based energy method for estimating vehicle interior noise in early vehicle design. SAE Technical Papers, 2009.

[47] Gur Y., Pan J., Wagner D. Sound package development for lightweight vehicle design using statistical energy analysis (SEA). SAE Technical Paper 2015-01-2302, 2015.

[48] De Langhe K., Vansant K., Hallez R., Beriot H. Advanced simulation techniques for vehicle acoustic panel loading predictions, including FEM AML and fast multipole BEM (FMBEM). 40th International Congress and Exposition on Noise Control Engineering, Vol. 1, 2011, p. 789-802. 
[49] Lee S.-K., Kim B.-S., Park D.-C. Objective evaluation of the rumbling sound in passenger cars based on an artificial neural network. Proceedings of the Institution of Mechanical Engineers - Part D: Journal of Automobile Engineering, Vol. 219, Issue 4, 2005, p. 457-469.

[50] Peng W., Jin C., Zhou H. An experimental study on the influence of tire noise on the sound quality of car interior noise. 39th International Congress on Noise Control Engineering, Vol. 5, 2010, p. 3579-3586.

[51] Lalor P. The prediction of low- and mid-frequency internal road vehicle noise: a literature survey. Proceedings of the Institution of Mechanical Engineers, Part D: Journal of Automobile Engineering, Vol. 221, 2007, p. 245-269.

[52] Harrison M. Vehicle Refinement: Controlling Noise and Vibration in Road Vehicles. Elsevier, MA, USA, 2004.

[53] Chen C., Kuan Y., Chen C., Sung M. Using CFD technique to investigate the effect of tire roiling-noise with different pattern design. Applied Mechanics and Materials, Vol. 575, 2014, p. 469-472.

[54] Wayson L. R. On-Board Sound Intensity (OBSI) Study, Phase 2, Summary. Final Report, FDOT Project No. \#BDT06, 2014.

[55] Heckl M. Tire noise generation. Wear, Vol. 113, 1986, p. 157-170.

[56] Future Noise Policy. European Commission Green Paper, COM (96) 540 final, Brussels, 1996.

[57] Remington P. J., Dixon N. R., Wittig L. E., Kurzweily L. G., Menge C. W., Stahr J. D. Control of Wheel/Rail Noise and Vibration. US DOT Report DOT-TSC-UMTA-82-57, 1983.

[58] Murphy E., King E. A. Scenario analysis and noise action planning: modelling the impact of mitigation measures on population exposure. Applied Acoustics, Vol. 72, Issue 8, 2011, p. 487-494.

[59] Kim R. Burden of disease from environmental noise. WHO International Workshop on Combined Environmental Exposure: Noise, Air Pollutants and Chemicals, 2007.

[60] Pan L., Boulet J. A. M. Noise exposure level of the drivers of heavy duty diesel trucks. Noise Control Engineering Journal, Vol. 62, Issue 3, 2014, p. 132-137.

[61] Goodwin S. E., Shriver W. G. Effects of traffic noise on occupancy patterns of forest birds. Conservation Biology, Vol. 25, Issue 2, 2011, p. 406-411.

[62] Lengagne T. Traffic noise affects communication behaviour in a breeding anuran, Hyla arborea. Biological Conservation, Vol. 141, Issue 8, 2008, p. 2023-2031.

[63] Bee M. A., Swanson E. M. Auditory masking of anuran advertisement calls by road traffic noise. Animal Behaviour, Vol. 74, 2007, p. 1765-1776.

[64] Council Directive 70/157/EEC. 6 February 1970 on the Approximation of the Laws of the Member States Relating to the Permissible Sound Level and the Exhaust System of Motor Vehicles, 1970.

[65] Directive 2002/49/EC of the European Parliament and of the Council of 25 June 2002 Relating to the Assessment and Management of Environmental Noise. EC, 2002.

[66] Regulation (EU) No 540/2014 of the European Parliament and of the Council of 16 April 2014 on the Sound Level of Motor Vehicles and of Replacement Silencing Systems, and Amending Directive 2007/46/EC and Repealing Directive 70/157/EEC. EU, 2014.

[67] Regulation (EU) No 168/2013 of the European Parliament and of the Council of 15 January 2013 on the Approval and Market Surveillance of Two- Or Three-Wheel Vehicles and Quadricycles. EU, 2013.

[68] Directive 2001/43/EC of the European Parliament and of the Council of 27 June 2001 Amending Council Directive 92/23/EEC Relating to Tyres for Motor Vehicles and Their Trailers and to Their Fitting. EC, 2001.

[69] Tyre/Road Noise. Forum of European National Highway Research Laboratories, Final Report SI2.408210, 2001.

[70] Regulation (EC) No. 661/2009 of the European Parliament and of the Council of 13 July 2009 Concerning Type-Approval Requirements for the General Safety of Motor Vehicles, Their Trailers and Systems, Components and Separate Technical Units Intended Therefo. EC, 2009.

[71] Regulation (EC) No 1222/2009 of the European Parliament and of the Council of 25 November 2009 on the Labelling of Tyres with Respect to Fuel Efficiency and Other Essential Parameters. EC, 2009.

[72] ECE R117/2011 Uniform Provisions Concerning the Approval of Tyres with Regard to Rolling Sound Emissions and to Adhesion on Wet Surfaces and/or to Rolling Resistance. UNECE, 2011.

[73] ECE R51 Agreement concerning the Adoption of Uniform Technical Prescriptions for Wheeled Vehicles, Equipment and Parts Which Can Be Fitted and/or Be Used on Wheeled Vehicles and the Conditions for Reciprocal Recognition of Approvals. UN/ECE, 2011. 
[74] Vehicle Noise - Setting the Right Sound Levels. European Automobile Manufacturers' Association (ACEA), 2012.

[75] Nijland R., Vos E., Hooghwerff J. The dutch noise innovation program road traffic (IPG). 32nd International Congress and Exposition on Noise Control Engineering, 2003.

[76] China Green Tyre Rating Assessment (C-GTRA). RenminWang, 2016, http://auto.people.com.cn /n1/2016/0424/c1005-28300099.html.

[77] Tyre Labelling. European Tyre \& Rubber Manufacturers' Association (ETRMA), http://www.etrma.org/tyres/tyre-labelling.

[78] Procedures for Abatement of Highway Traffic Noise and Construction Noise. Code 23, Section 772, Federal Highway Administration, 2010.

[79] Noise Assessment Criteria in Land Use Planning. Publication LU-131, Ontario Ministry of the Environment (MOE), Canada, 1997.

[80] The Noise Pollution (Regulation and Control) Rules. Central Pollution Control Board, Ministry of Environment and Forests, Government of India, New Delhi, India, 2000.

[81] Syamkumar A., Aditya K., Chowdary V. Development of mode-wise noise prediction models for the noise generated due to tyre-pavement surface interaction. Advanced Materials Research, Vol. 723, 2013, p. 50-57.

[82] Kim U., Maunder M., Grant P., Mawdsley D. Developing a car to meet new pass-by noise requirements using simulation and testing. SAE Technical Paper 2015-01-2319, 2015.

[83] Wang G., Shores R., Botts J., Hibbett R. On-Board Sound Intensity Tire-Pavement Noise Study in North Carolina. Report No. FHWA/NC/2010-13, East Carolina University, 2011.

[84] Plotkin K. J., Stusnick E. A Unified Set of Models for Tire/Road Noise Generation. Report: WR-8126, Environmental Protection Agency, Arlington, VA, 1981.

[85] Highway Traffic Noise: Analysis and Abatement Guidance. U.S. Department of Transportation, Federal Highway Administration, Office of Environmental and Planning, Noise and Air Quality Branch, Washington, D.C., 2010.

[86] Donovan P. R., Pierce L. M., Lodico D. M., Rochat J. L., Knauer H. S., Donavan P. R. Evaluating Pavement Strategies and Barriers for Noise Mitigation. NCHRP Report 738, 2013.

[87] Jones W. Highway Noise Control with HMA. Asphalt, 2002.

[88] Kohler E. OBSI Testing. Pavement Evaluation, Roanoke, Virginia, 2010.

[89] Jabben J., Verheijen E., Potma C. Noise reduction by electric vehicles in the Netherlands. 41st International Congress and Exposition on Noise Control Engineering, Vol. 3, 2012, p. 2505-2512.

[90] Mendonca C., Freitas E., Ferreira J. P., Raimundo I. D., Santos J. A. Noise abatement and traffic safety: the trade-off of quieter engines and pavements on vehicle detection. Accident Analysis and Prevention, Vol. 51, 2013, p. 11-17.

[91] Sandberg U. What is the biggest threat to health and safety-quiet or noisy vehicles. The Journal of the Acoustical Society of America, Vol. 134, 2013, p. 3979.

[92] Buckers C., Stockert U. Quiet Road Traffic 3 - Interdisciplinary approach to reduce the noise emission at the source. European Conference on Noise Control, 2012, p. 984-991.

[93] Mogrovejo D. E., Flintsch G. W., De Leon Izeppi E. D., Mcghee K. K., Burdisso R. A. Short-term effect of pavement surface aging on tire-pavement noise measured with onboard sound intensity methodology. Transportation Research Record, Vol. 2403, 2014, p. 17-27.

[94] Saemann E.-U., Dimitri G., Kindt P. Tire requirements for pavement surface characteristics. 7th Symposium on Pavement Surface Characteristics: SURF 2012, Norfolk, VA, 2012, p. 1-33.

[95] Iwao K., Yamazaki I. A study on the mechanism of tire/road noise. JSAE Review, Vol. 17, Issue 2, 1996, p. 139-144.

[96] Saemann E.-U., Dahlke M., Nolte B. Improving noise performance with sealed tyre and cavity absorber technology. 40th International Congress and Exposition on Noise Control Engineering, 2011, p. 593-599.

[97] Zhou H. Investigate into Influence of Tire tread Pattern on Noise and Hydroplaning and Synchronously Improving Methods. Ph.D. Dissertation, Jiangsu University, China, 2013.

[98] Zhou H., Wang G., Yang J., Ying S. Simulation and analysis of the bypass influences on tire noise. Research Journal of Applied Sciences, Engineering and Technology, Vol. 7, Issue 3, 2014, p. 576-580.

[99] Kakumu K. Low Noise Tyre. European Patent EP0402021 A2, 1990.

[100] Cusimano F. J. I. Low Noise Pneumatic Tire Tread and Method for Producing Same. European Patent EP0513676 A1, 1992. 
[101] Comfort Contact CC6. Continental AG, 2016, http://www.continental-tyres.com.my/car/tires/car /summer-plt/comfortcontactec6.

[102] Fitz F., Heck T. Development of tooling for a light weight steel Kühl wheel. SAE Technical Paper 2001-01-0750, 2001.

[103] Sainty S., Tawaf A., Richard J. J., Mohamed Z., Wang X. Analysis of potential solutions to audible tire cavity and rim coupling resonance noise. ASME Noise Control and Acoustics Division Conference, Vol. 6, 2012, p. 4457-4463.

[104] Molisani L. A Coupled Tire Structure-Acoustic Cavity Model. Ph.D. Dissertation, Virginia Tech, 2004.

[105] Kamiyama Y. Development of a new on-wheel resonator for tire cavity noise. SAE Technical Papers 2014-01-0022, 2014.

[106] Fernandez E. T. The Influence of Tyre Air Cavities on Vehicle Acoustics. Ph.D. Thesis, KTH University, Stockholm, Sweden, 2006.

[107] Yukawa N., Nishikawa M., Nakajima T., Aoki C., Sugihara H. Tire Noise Reducing System. U.S. Patent 6,726,289 B2 (assigned to Sumitomo), 2004.

[108] Pirelli Noise Cancelling System. Pirelli, 2013, https:/www.pirelli.com/tires/en-us/car-light-truck /original-equipment-tires/noise-cancelling-system.

[109] Mohamed Z., Wang X. A study of tyre cavity resonance and noise reduction using inner trim. Mechanical Systems and Signal Processing, Vols. 50-51, 2015, p. 498-509.

[110] Schmidt K. C., Majumdar R. N. Tech service: silencing tire noise. Rubber World, Vol. 244, Issue 6, 2011.

[111] Pirelli Absorbs Tire Noise with PU Sponge. Tire Business, 2013, http://www.tirebusiness.com /article/20130717/NEWS/130719921/pirelli-absorbs-tire-noise-with-pu-sponge.

[112] Morgan C. D. Tire Tread Pitch Sequencing for Reduced Noise. US Patent US6363984, 2002.

[113] Hoffmeister K., Bernard J. Tread pitch arrangement optimization through the use of a genetic algorithm. Tire Science and Technology, Vol. 26, Issue 1, 1998, p. 2-22.

[114] Li T., Feng J., Burdisso R., Sandu C. The effects of tread pattern on tire pavement interaction noise. 45th International Congress and Exposition on Noise Control Engineering: Towards a Quieter Future, 2016.

[115] Li T., Feng J., Burdisso R., Sandu C. The effects of tread pattern on tire pavement interaction noise. 45th International Congress and Exposition on Noise Control Engineering: Towards a Quieter Future, Hamburg, Germany, 2016, p. 2185-2196.

[116] Aboutorabi H. M. R., Kung L. Application of coupled structural acoustic analysis and sensitivity calculations to a tire noise problem. Tire Science and Technology, Vol. 40, Issue 1, 2012, p. 25-41.

[117] Li T., Burdisso R., Sandu C. The effect of rubber hardness and tire size on tire-pavement interaction noise. 36th Annual Meeting and Conference on Tire Science and Technology, Akron, Ohio, USA, 2017.

[118] Lee D. W., Kim J. K., Kim S. R., Lee K.-H. Shape design of a tire contour based on approximation model. Journal of Mechanical Science and Technology, Vol. 25, Issue 1, 2011, p. 149-155.

[119] Sandberg U., Ejsmont J. A., Mioduszewski P., Taryma S. Relation between noise emission, friction and rolling resistance of car tires - a pilot study. Inter-Noise, Christchurch, New Zealand, 1998.

[120] Sandberg U., Ejsmont J. A. Noise emission, friction and rolling resistance of car tires - summary of an experimental study. Proceedings of NOISE-CON, Newport Beach, California, 2000.

[121] Kim E.-Y., Hwang S.-W., Lee S.-K. Image-based approach to optimize the tyre pitch sequence for a reduction in the air-pumping noise based on a genetic algorithm. Proceedings of the Institution of Mechanical Engineers, Part D: Journal of Automobile Engineering, Vol. 226, Issue 9, 2012, p. 1171-1184.

[122] Nelson P. M., Harris G. J., Robinson B. J. An examination of the relationship between tyre noise and safety performance. Project Report PR047/93, Transport Research Laboratory, Crowthorne, England, 1993.

[123] Rasmussen R. O. Quieter concrete pavements - an update of pooled fund TPF-5 (139). Pavement Evaluation, Roanoke, Virginia, 2010.

[124] Mcghee K. Virginia quiet pavement study. SURF, Norfolk, VA, 2012.

[125] Dai L., Lee H. S. Ray acoustics approach to quantitative prediction of highway traffic noise. ASME International Mechanical Engineering Congress and Exposition, Vol. 8, 2010, p. 223-228.

[126] Neithalath N. Development and Characterization of Acoustically Efficient Cementitious Materials. Ph.D. Dissertation, Purdue University, 2004. 
[127] Neithalath N., Weiss J., Olek J. Reducing the Noise Generated in Concrete Pavements through Modification of the Surface Characteristics. PCA R\&D Serial No. 2878, 2005.

[128] Hofman R., Van Der Kooij J. Results from the dutch noise innovation program road traffic (IPG) and roads to the future program (WnT). 32nd International Congress and Exposition on Noise Control Engineering, 2003.

[129] Maennel M., Forssen J., Van Der Aa B. Improving the acoustic performance of low noise road surfaces using resonators. Proceedings of Meetings on Acoustics, 2013.

[130] Nilsson N.-A. Noise reduction mechanisms for poroelastic road surfaces. Proceeding of International Tire/Road Noise Conference, Gothenburg, Sweden, 1990, p. 47-66.

[131] Sandberg U., Goubert L. Poroelastic road surface (PERS): a review of 30 years of R\&D work. Proceeding of Inter-Noise, Osaka, Japan, 2011.

[132] Nilsson N.-A. Possible method of reducing external tyre noise. Proceedings of the International Tire Noise Conference, Stockholm, Sweden, 1979.

[133] Li T. Tire-Pavement Interaction Noise (TPIN) Modeling Using Artificial Neural Network (ANN). Ph.D. Dissertation, Virginia Tech, 2017.

[134] Fong S. Tyre noise predictions from computed road surface texture induced contact pressure. Proceedings of INTER-NOISE, Christchurch, New Zealand, 1998, p. 137-140.

[135] Van Blokland G., Van Leeuwen M. Efficiency of the combined application of silent tyres and silent road surfaces. 39th International Congress on Noise Control Engineering, Vol. 5, 2010, p. 3469-3478.

[136] Berge T., Haukland F. Low-noise tyres-in-use - Do they exist? 40th International Congress and Exposition on Noise Control Engineering, Vol. 1, 2011, p. 518-529.

[137] Couche J. C., Fuller C. R. Active control of automobile cabin noise with advanced speakers. 136th Acoustical Society of America Meeting, Norfolk, VA, 1998.

[138] Sun G., Li M., Lim T. C. Modified filtered-x LMS algorithm for active control of vehicle road impact noise. 41st International Congress and Exposition on Noise Control Engineering, Vol. 1, 2012, p. 58-69.

[139] Zafeiropoulos N., Moorhouse A., Mackay A., Ballatore M. Active control of structure-borne road noise based on the separation of front and rear structural road noise related dynamics. SAE International Journal of Passenger Cars - Mechanical Systems, Vol. 8, Issue 3, 2015, p. 886-891.

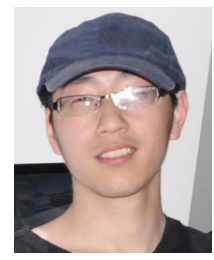

Tan Li received his B.S. in automotive engineering from Tongji University in China with Summa Cum Laude in 2013. He earned his Ph.D. in mechanical engineering from Virginia Tech in 2017. Then he has been working at Maxxis Technology Center as a Senior NVH Engineer in Atlanta, GA, leading the projects on NVH (Noise, Vibration and Harshness) and vehicle/tire dynamics. 